\title{
Metabotropic Glutamate Receptor 7: A New Therapeutic Target in Neurodevelopmental Disorders
}

\author{
Nicole M. Fisher ${ }^{1 t}$, Mabel Seto ${ }^{1+}$, Craig W. Lindsley ${ }^{1,2}$ and Colleen M. Niswender ${ }^{1,3 *}$ \\ 'Department of Pharmacology and Vanderbilt Center for Neuroscience Drug Discovery, Vanderbilt University, Nashville, TN, \\ United States, ${ }^{2}$ Department of Chemistry, Vanderbilt University, Nashville, TN, United States, ${ }^{3}$ Vanderbilt Kennedy Center, \\ Vanderbilt University Medical Center, Nashville, TN, United States
}

OPEN ACCESS

Edited by:

Enza Palazzo,

Università degli Studi della Campania

"Luigi Vanvitelli" Naples, Italy

Reviewed by:

Santina Chiechio,

Università degli Studi di Catania, Italy

Francesca Guida,

Università degli Studi della Campania

"Luigi Vanvitelli" Naples, Italy

${ }^{*}$ Correspondence:

Colleen M. Niswender

Colleen.niswender@vanderbilt.edu

tThese authors have contributed equally to this work

Received: 29 June 2018 Accepted: 01 October 2018 Published: 23 October 2018

Citation:

Fisher NM, Seto M, Lindsley CW and Niswender CM (2018) Metabotropic

Glutamate Receptor 7: A New

Therapeutic Target

in Neurodevelopmental Disorders.

Front. Mol. Neurosci. 11:387.

doi: 10.3389/fnmol.2018.00387
Neurodevelopmental disorders (NDDs) are characterized by a wide range of symptoms including delayed speech, intellectual disability, motor dysfunction, social deficits, breathing problems, structural abnormalities, and epilepsy. Unfortunately, current treatment strategies are limited and innovative new approaches are sorely needed to address these complex diseases. The metabotropic glutamate receptors are a class of $G$ protein-coupled receptors that act to modulate neurotransmission across many brain structures. They have shown great promise as drug targets for numerous neurological and psychiatric diseases. Moreover, the development of subtype-selective allosteric modulators has allowed detailed studies of each receptor subtype. Here, we focus on the metabotropic glutamate receptor $7\left(\mathrm{mGlu}_{7}\right)$ as a potential therapeutic target for NDDs. mGlu 7 is expressed widely throughout the brain in regions that correspond to the symptom domains listed above and has established roles in synaptic physiology and behavior. Single nucleotide polymorphisms and mutations in the GRM7 gene have been associated with idiopathic autism and other NDDs in patients. In rodent models, existing literature suggests that decreased $\mathrm{mGlu}_{7}$ expression and/or function may lead to symptoms that overlap with those of NDDs. Furthermore, potentiation of mGlu7 activity has shown efficacy in a mouse model of Rett syndrome. In this review, we summarize current findings that provide rationale for the continued development of mGlu 7 modulators as potential therapeutics.

Keywords: neurodevelopmental disorder, ASD, Rett syndrome, mGlu 7 , GRM7, allosteric modulator

Abbreviations: ADHD, attention deficit hyperactivity disorder; ADX71743, (+)-6-(2,4-dimethylphenyl)-2ethyl-6,7-dihydrobenzo[d]oxazol-4(5H)-one; $\quad$ ADX88178, $\quad$ 5-methyl- $N$-(4-methylpyrimidin-2-yl)-4-(1H-pyrazol4-yl)thiazol-2-amine; AMN082, N,N'-dibenzhydrylethane-1,2-diamine dihydrochloride; ASDs, autism spectrum disorders; CaM, calmodulin; cAMP, cyclic adenosine monophosphate; CNS, central nervous system; EC50, effective concentration 50; ELFN1, extracellular-leucine-rich repeat fibronectin type III domain containing 1; EPM, elevated plus maze; GABA, $\gamma$-aminobutyric acid; GIRK, G protein inwardly rectifying potassium channel; GPCR, G protein-coupled receptor; GTP $\gamma$, guanosine 5'-O- $[\gamma$-thio $]$ triphosphate; IC50, inhibitory concentration 50; ID, intellectual disability; L-AP4, L-2-amino-4-phosphonobutyric acid; LiCl, lithium chloride; LSP1-2111, (2S)2-amino-4-[hydroxy[hydroxy(4-hydroxy-3-methoxy-5-nitro-phenyl)methyl]phosphoryl]butanoic acid; LSP2-9166, (2S)-2-amino-4-(((4-(carboxymethoxy)-3-(trifluoromethoxy)phenyl)(hydroxy)methyl)(hydroxy)phosphoryl)butanoic acid; LSP4-2022, (2S)-2-amino-4-(\{[4-(carboxymethoxy)phenyl](hydroxy)methyl\}(hydroxy)phosphoryl)butanoic acid; LTD, long-term depression; LTP, long-term potentiation; LY341495, (2S)-2-amino-2-[(1S,2S)-2-carboxycycloprop-1-yl]3-(xanth-9-yl)propanoic acid; MacMARCKS, macrophage myristoylated alanine-rich C-kinase substrate; MDS, MECP2 Duplication syndrome; MeCP2, methyl-CpG binding protein 2; mGlu, metabotropic glutamate receptor; MMPIP, 6-(4-methoxyphenyl)-5-methyl-3-pyridin-4-ylisoxazolo[4,5-c]pyridin-4(5H)-one; MRG, mortality factorrelated gene; NAM, negative allosteric modulator; NDDs, neurodevelopmental disorders; NK1, neurokinin-1 receptor; OLM, oriens-lacunosum-moleculare; PAM, positive allosteric modulator; PICK1, protein interacting with C kinase 1 , 


\section{INTRODUCTION}

Neurodevelopmental disorders are a group of conditions that present in early life and are characterized by the failure to meet typical developmental milestones. These disorders affect a significant fraction of the population: $15 \%$ of children aged 3 to 17 years old were reported to have a developmental disability in the years 2006 to 2008 (Boyle et al., 2011). The current Diagnostic and Statistical Manual of Mental Disorders (DSM-V) categorizes NDDs into six groups: intellectual disabilities (IDs), learning disorders, communication disorders, ASDs, ADHDs, and motor disorders (American Psychiatric Association, 2013). There is often overlap between these groups; for example, $31.6 \%$ of patients with ASD also fulfill the diagnostic criteria for ID (Christensen et al., 2016). In addition, NDDs are associated with many co-morbidities, including but not limited to: epilepsy, mood disorders, breathing abnormalities, sleep problems, and gastrointestinal issues (Mannion and Leader, 2013; Doshi-Velez et al., 2014). Individuals with NDDs can struggle to develop interpersonal relationships and face immense challenges in school and in the workforce. Treatment options remain limited and there is a great need to identify novel points of intervention to improve the quality of life of these patients.

A growing body of literature suggests that NDDs arise from complex interactions between the environment and the genome (van Loo and Martens, 2007; Hu et al., 2014). In some cases, NDDs can be traced to genetic abnormalities such as point mutations, gene deletions/duplications, or chromosomal rearrangements. Examples of such disorders include Down syndrome, RTT, Fragile X syndrome, and Angelman syndrome. Although a clear genetic cause is often rare, monogenetic disorders have helped to identify proteins and pathways that are required for proper neuronal development and maintenance. Interestingly, many genes that have been associated with syndromic and non-syndromic NDDs can be clustered into pathways involved in synaptic structure and function (Spooren et al., 2012; Sztainberg and Zoghbi, 2016). In this review, we focus on the metabotropic glutamate receptor $7\left(\mathrm{mGlu}_{7}\right)$, a GPCR that serves as an important regulator of synaptic transmission and plasticity. We will summarize current literature suggesting the involvement of $\mathrm{mGlu}_{7}$ in NDDs and discuss its potential utility as a novel therapeutic target.

\section{METABOTROPIC GLUTAMATE RECEPTORS}

$\mathrm{mGlu}_{7}$ is one of eight subtypes of mGlu that are expressed throughout the body. The mGlu receptors are a family of Class $\mathrm{C}$ GPCRs that are further divided into three groups based on their

PIH, phosphatidylinositol hydrolysis; PKA, protein kinase A; PKC, protein kinase C; PLC, phospholipase C; PTZ, pentylenetetrazole; RTT, Rett syndrome; SC-CA1, Schaffer Collateral-CA1; SLIN, stratum lucidum interneuron; SNP, single nucleotide polymorphism; VFD, Venus flytrap domain; VU6005649, 3-(2,3-difluoro-4-methoxy-phenyl)-2,5-dimethyl-7(trifluoromethyl)pyrazolo[1,5-a]pyrimidine; VU6010608, 3,4-dimethoxy- $N$ [2-(1H-1,2,4-triazol-1-yl)-5-(trifluoromethoxy)phenyl]benzamide; XAP044, 7-hydroxy-3-(4-iodophenoxy)-4H-chromen-4-one. sequence homology, signaling pathways, and ligand selectivity. Group I includes $\mathrm{mGlu}_{1}$ and $\mathrm{mGlu}_{5}$, Group II includes mGlu and $\mathrm{mGlu}_{3}$, and Group III includes $\mathrm{mGlu}_{4}, \mathrm{mGlu}_{6}, \mathrm{mGlu}_{7}$, and mGlu $_{8}$ (Niswender and Conn, 2010). Characteristic of Class C GPCRs, all mGlu receptors consist of a large $N$-terminal ligand binding domain, a cysteine-rich domain, a heptahelical domain, and a C-terminal domain; G proteins interact with intracellular loops and the C-terminus of the receptors.

The large extracellular $N$-terminal ligand binding domain consists of two lobes that sit on top of one another, similar to a Venus flytrap. This structural similarity earned it the name VFD. Glutamate, the endogenous ligand for mGlu receptors, binds to a cleft in between the two lobes of the VFD (Kunishima et al., 2000; Pin et al., 2003; Niswender and Conn, 2010). The mGlu receptors function as constitutive dimers (Pin et al., 2005; El Moustaine et al., 2012), and dimerization primarily occurs at the level of the VFDs (Kunishima et al., 2000; Jingami et al., 2003; Pin et al., 2003; Levitz et al., 2016). The VFDs can exist in three different states within the dimer: open-open, openclosed, and closed-closed. The open-open state is the inactive state, and upon glutamate binding to the cleft of the VFD, the VFD closes and receptor activation occurs. Ligand binding to one VFD results in the open-closed conformation, whereas ligand binding to both VFDs results in the closed-closed conformation (Pin et al., 2005; Muto et al., 2007). It is suggested that glutamate binding to one VFD alone is sufficient for activation (openclosed), but that full activation is achieved when both VFDs are ligand bound (closed-closed) (Kniazeff et al., 2004). Although mGlu $_{7}$ has been historically predicted to act as a homodimer, it has also been postulated that the receptor enacts some of its function through hetero-dimerization with other receptors, such as $\mathrm{mGlu}_{8}$ (Doumazane et al., 2011; Kammermeier, 2015).

The cysteine-rich domain contains nine cysteine residues linked by disulfide bonds that are critical for propagating signals from the VFDs to the rest of the receptor (Rondard et al., 2006; Muto et al., 2007). After glutamate binding, signals are transduced through the cysteine-rich domain to the heptahelical domain where conformational changes allow for $G$ protein coupling (Kunishima et al., 2000; Tateyama et al., 2004; Binet et al., 2007; Muto et al., 2007; El Moustaine et al., 2012). mGlu and the other Group III mGlu receptors couple to $\mathrm{G}_{\mathrm{i} / \mathrm{o}}$, which inhibits adenylyl cyclase activity and reduces intracellular cAMP concentrations (Niswender and Conn, 2010). Furthermore, $\mathrm{mGlu}_{7}$ activation can result in $\mathrm{K}^{+}$influx via $\mathrm{G}_{\beta \gamma}$-mediated opening of GIRK ion channels, and inhibition of $\mathrm{Ca}^{2+}$ currents through N- and P/Q- type calcium channels (Millán et al., 2002, 2003; Martín et al., 2007).

$\mathrm{mGlu}_{7}$ is the most widely expressed mGlu receptor in the CNS with relatively high expression in the amygdala, hippocampus, and hypothalamus (Kinoshita et al., 1998). There are 15 splice variants of GRM7, six of which are predicted to be protein coding (Zerbino et al., 2018). The two major isoforms, mGlu and $\mathrm{mGlu}_{7 \mathrm{~b}}$, differ at their $\mathrm{C}$-termini and it is hypothesized that these distinct $\mathrm{C}$-terminal tails mediate different proteinprotein interactions (Dev et al., 2001). While mGlu $_{7 a}$ and mGlu $_{7 b}$ are primarily expressed in the CNS (Flor et al., 1997; Corti et al., 1998; Kosinski et al., 1999), isoform specificity 
TABLE 1 | Summary of current tool compounds used to study mGlu 7.

\begin{tabular}{|c|c|c|c|c|c|c|}
\hline Name (\#) & Type & $\mathrm{mGlu}_{7} \mathrm{pEC}_{50} / \mathrm{plC}_{50}$ & $\mathrm{mGlu}_{8} \mathrm{pEC}_{50} / \mathrm{plC}_{50}$ & $\mathrm{mGlu}_{4} \mathrm{pEC}_{50} / \mathrm{pIC}_{50}$ & $\mathrm{mGlu}_{6} \mathrm{pEC}_{50} / \mathrm{plC}_{50}$ & Source \\
\hline \multirow[t]{2}{*}{ L-AP4 (1) } & Orthosteric agonist & $3.47(\mathrm{PIH})$ & $6.53(\mathrm{PIH})$ & $7.00(\mathrm{PIH})$ & $5.62(\mathrm{PIH})$ & Acher et al., 2012; \\
\hline & & $3.61\left(\mathrm{Ca}^{2+}\right)$ & $6.53\left(\mathrm{Ca}^{2+}\right)$ & $6.89\left(\mathrm{Ca}^{2+}\right)$ & $6.00\left(\mathrm{Ca}^{2+}\right)$ & Selvam et al., 2018 \\
\hline LSP4-2022 (2) & Orthosteric agonist & $4.34\left(\mathrm{Ca}^{2+}\right)$ & $4.54\left(\mathrm{Ca}^{2+}\right)$ & $6.96\left(\mathrm{Ca}^{2+}\right)$ & $5.36\left(\mathrm{Ca}^{2+}\right)$ & $\begin{array}{l}\text { Acher et al., 2012; } \\
\text { Goudet et al., 2012; } \\
\text { Selvam et al., } 2018\end{array}$ \\
\hline \multirow[t]{2}{*}{ LSP1-2111 (3) } & Orthosteric agonist & $4.28(\mathrm{PIH})$ & $4.18(\mathrm{PIH})$ & $5.66(\mathrm{PIH})$ & $5.77(\mathrm{PIH})$ & Selvam et al., 2018 \\
\hline & & $4.00\left(\mathrm{Ca}^{2+}\right)$ & $4.71\left(\mathrm{Ca}^{2+}\right)$ & $6.05\left(\mathrm{Ca}^{2+}\right)$ & $5.49\left(\mathrm{Ca}^{2+}\right)$ & \\
\hline LSP2-9166 (4) & Orthosteric agonist & $5.71\left(\mathrm{Ca}^{2+}\right)$ & $4.25\left(\mathrm{Ca}^{2+}\right)$ & $7.22\left(\mathrm{Ca}^{2+}\right)$ & Not reported & Acher et al., 2012 \\
\hline VU0422288 (5) & Group III PAM & $6.85\left(\mathrm{Ca}^{2+}\right)$ & $6.93\left(\mathrm{Ca}^{2+}\right)$ & $6.98\left(\mathrm{Ca}^{2+}\right)$ & Not reported & $\begin{array}{l}\text { Jalan-Sakrikar et al., } \\
2014\end{array}$ \\
\hline VU0155094 (6) & Group III PAM & $5.80\left(\mathrm{Ca}^{2+}\right)$ & $6.07\left(\mathrm{Ca}^{2+}\right)$ & $5.48\left(\mathrm{Ca}^{2+}\right)$ & Not reported & $\begin{array}{l}\text { Jalan-Sakrikar et al., } \\
2014\end{array}$ \\
\hline ADX88178 (7) & $\mathrm{mGlu}_{4 / 8}$ PAM & $>4.52\left(\mathrm{Ca}^{2+}\right)$ & $5.66\left(\mathrm{Ca}^{2+}\right)$ & $8.46\left(\mathrm{Ca}^{2+}\right)$ & $>5$ & Le Poul et al., 2012 \\
\hline \multirow[t]{2}{*}{ ADX71743 (8) } & $\mathrm{mGlu}_{7} \mathrm{NAM}$ & 7.20 (human, $\mathrm{Ca}^{2+}$ ) & Inactive & Inactive & Inactive & Kalinichev et al., 2013 \\
\hline & & $7.06\left(\right.$ rat, $\left.\mathrm{Ca}^{2+}\right)$ & Inactive & Inactive & Inactive & \\
\hline AMN082 (9) & Allosteric agonist & $6.59(\mathrm{GTP} \gamma \mathrm{S})$ & $>5(\mathrm{GTP} \gamma \mathrm{S})$ & $>5(\mathrm{GTP} \gamma \mathrm{S})$ & $>5(\mathrm{GTP} \gamma \mathrm{S})$ & Mitsukawa et al., 2005 \\
\hline \multirow[t]{2}{*}{ XAP044 (10) } & Antagonist & 5.26 (cAMP) & 4.48 (cAMP) & Inactive & Inactive & Gee et al., 2014 \\
\hline & & 5.55 to $5.46(\mathrm{GTP} \gamma \mathrm{S})$ & & & & \\
\hline LY341495 (11) & $\begin{array}{l}\text { Orthosteric } \\
\text { antagonist }\end{array}$ & 6.00 (cAMP) & 6.76 (cAMP) & 4.66 (cAMP) & Not reported & Kingston et al., 1998 \\
\hline \multirow[t]{3}{*}{ MMPIP (12) } & $\mathrm{mGlu}_{7} \mathrm{NAM}$ & 6.66 (cAMP) & $>5(\mathrm{cAMP})$ & $>5(\mathrm{cAMP})$ & Not reported & Suzuki et al., 2007 \\
\hline & & $7.15\left(\mathrm{Ca}^{2+}\right)$ & & & & Niswender et al., 2010 \\
\hline & & 6.14 (Thallium) & & & & Niswender et al., 2010 \\
\hline VU6010608 (13) & $\mathrm{mGlu}_{7}$ NAM & $6.12\left(\mathrm{Ca}^{2+}\right)$ & $>5\left(\mathrm{Ca}^{2+}\right)$ & $>5\left(\mathrm{Ca}^{2+}\right)$ & Inactive $(>5)$ & Reed et al., 2017 \\
\hline VU6005649 (14) & $\mathrm{mGlu}_{7 / 8}$ PAM & $6.19\left(\mathrm{Ca}^{2+}\right)$ & $5.59\left(\mathrm{Ca}^{2+}\right)$ & $>5\left(\mathrm{Ca}^{2+}\right)$ & Inactive & Abe et al., 2017 \\
\hline
\end{tabular}

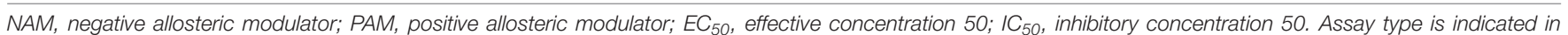
parenthesis: PIH, phosphatidylinositol hydrolysis; CAMP, cAMP accumulation; $\mathrm{Ca}^{2+}$, calcium mobilization; GTP $\gamma$ S, GTP $\gamma$ S binding.

has been observed in peripheral tissues such as the testes, trachea, uterus, and salivary gland (Schulz et al., 2002). In the $\mathrm{CNS}, \mathrm{mGlu}_{7}$ receptors are primarily localized to presynaptic active zones in neurons where they can act as auto- or heteroreceptors to inhibit the release of their endogenous ligand, glutamate, the main excitatory neurotransmitter or GABA, the main inhibitory neurotransmitter, respectively (Shigemoto et al., 1996; Cartmell and Schoepp, 2000; Dalezios et al., 2002; Somogyi et al., 2003; Niswender and Conn, 2010). Compared to the other Group III mGlu receptors, $\mathrm{mGlu}_{7}$ exhibits an extremely low affinity for glutamate (high $\mu \mathrm{M}$ to $\mathrm{mM}$ as opposed to high $\mathrm{nM}$ to low $\mathrm{mM}$ for the other Group III mGlu receptors). Because of this low affinity, it has been suggested that $\mathrm{mGlu}_{7}$ functions as an "emergency brake" in the case of elevated glutamate levels (Niswender and Conn, 2010). This idea is supported by the observation that $\mathrm{mGlu}_{7}$ knockout mice exhibit spontaneous seizures under certain contexts (Sansig et al., 2001).

\section{CURRENT mGIu 7 TOOL COMPOUNDS}

Research to investigate $\mathrm{mGlu}_{7}$ biology has been limited, in part, due to the lack of selective tool compounds. Many of the currently existing compounds do not demonstrate high selectivity, desired pharmacokinetic properties, and/or high potency. Here, we review compounds currently available that will be mentioned in subsequent sections (compound properties at Group III mGlu receptors listed in Table $\mathbf{1}$ and structures in Figure 1).

The development of $\mathrm{mGlu}_{7}$ PAMs and other activators has been a major challenge thus far. Many in vitro and in vivo studies examining the effects of $\mathrm{mGlu}_{7}$ potentiation have been performed with orthosteric Group III mGlu agonists such as L-2amino-4-phosphonobutyric acid (L-AP4, 1), LSP4-2022 (2), and LSP1-2111 (3). L-AP4 exhibits an in vitro potency $\left(\mathrm{EC}_{50}\right)$ of 0.1 , 337, and $0.29 \mu \mathrm{M}$ at $\mathrm{mGlu}_{4}, \mathrm{mGlu}_{7}$, and $\mathrm{mGlu}_{8}$, respectively (Acher et al., 2012; Selvam et al., 2018). Similarly, LSP4-2022 exhibits in vitro $\mathrm{EC}_{50 \mathrm{~s}}$ of $0.11,11.6$, and $29.2 \mu \mathrm{M}$ at $\mathrm{mGlu}_{4}$, $\mathrm{mGlu}_{7}$, and $\mathrm{mGlu}_{8}$, respectively (Acher et al., 2012; Goudet et al., 2012; Selvam et al., 2018), while a structurally-related analog, LSP1-2111, displays $\mathrm{EC}_{50 \text { s }}$ of 2.2, 53, and $66 \mu \mathrm{M}$ at each of these receptors (Selvam et al., 2018). In addition to their relatively low potency at $\mathrm{mGlu}_{7}$, these orthosteric agonists have activity at the other Group III mGlu receptors, limiting their utility for the specific exploration of $\mathrm{mGlu}_{7}$ biology. Interestingly, the orthosteric $\mathrm{mGlu}_{4 / 7}$-preferring agonist LSP2-9166 is much more potent at $\mathrm{mGlu}_{7}$ compared to the other agonists described above $\left(\mathrm{EC}_{50 \mathrm{~s}}=0.06,1.97,55.6 \mu \mathrm{M}\right.$ at $\mathrm{mGlu}_{4}, \mathrm{mGlu}_{7}$, and $\left.\mathrm{mGlu}_{8}\right)$, but has yet to be investigated further in learning and memory paradigms (Acher et al., 2012; Hajasova et al., 2018; Lebourgeois et al., 2018).

Pan-Group III PAMs such as VU0422288 (5), which exhibits $\mathrm{EC}_{50 \mathrm{~s}}$ of 108,146 , and $125 \mathrm{nM}$, for $\mathrm{mGlu}_{4}, \mathrm{mGlu}_{7}$, and $\mathrm{mGlu}_{8}$, 


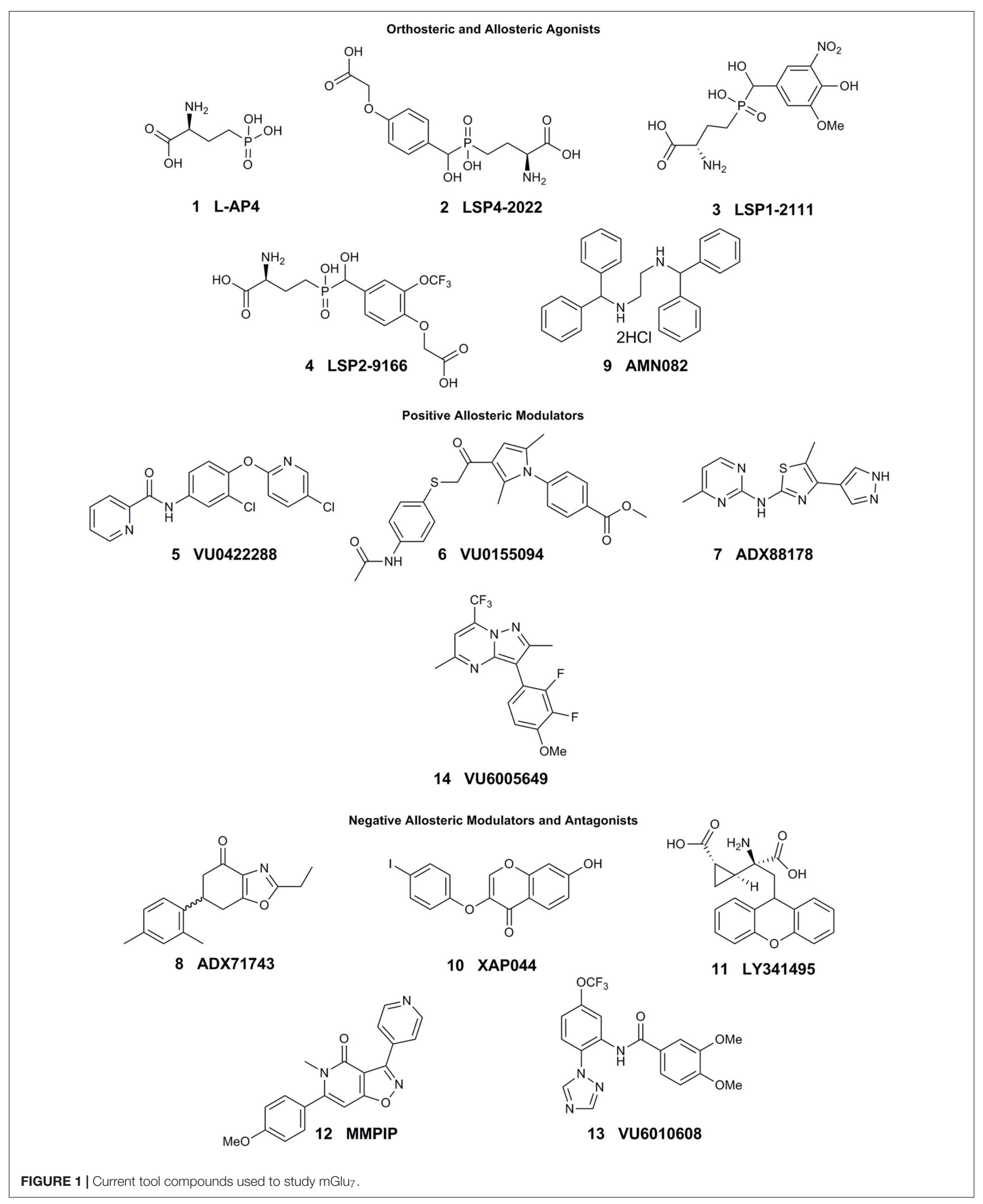


respectively, and VU0155094 (6), 3.2, 1.5, and 0.9 $\mu \mathrm{M}$ (JalanSakrikar et al., 2014) are also used. Additionally, VU6005649 14) is a dual $\mathrm{mGlu}_{7 / 8} \mathrm{PAM}$, with $\mathrm{EC}_{50}$ values of $650 \mathrm{nM}$ and $2.6 \mu \mathrm{M}$ at $\mathrm{mGlu}_{7}$ and $\mathrm{mGlu}_{8}$, respectively. In addition to its activity on $\mathrm{mGlu}_{8}$, VU6005649 displays off-target effects at the neurokinin1 receptor $(\mathrm{NK} 1)$. It is believed that these effects on NK1 may mediate sedative effects of this compound, which are observed in both wild-type and $\mathrm{mGlu}_{7}$ knockout animals (Abe et al., 2017). Because many of these tool compounds are not selective, they have been used concomitantly with other molecules, such as the mGlu $_{4 / 8}$ PAM ADX88178 (7) or mGlu 7 NAM ADX71743 (8), to confirm mGlu 7 -mediated effects (Le Poul et al., 2012; Kalinichev et al., 2013, 2014; Gogliotti et al., 2017).

To date, only one $\mathrm{mGlu}_{7}$-selective allosteric agonist, AMN082 $\left(9, \mathrm{EC}_{50}=260 \mathrm{nM}\right)$, has been reported in the primary literature (Mitsukawa et al., 2005). AMN082 has been used for animal studies involving learning and memory and plasticity in the amygdala among other areas. However, it has been shown that AMN082 exhibits off-target effects, one of which is predicted to be inhibition of the serotonin transporter (SERT) (Sukoff Rizzo et al., 2011; Ahnaou et al., 2016), somewhat limiting its utility in vivo unless coupled with knockout studies.

In contrast to potentiators, there have been several $\mathrm{mGlu}_{7}$ selective antagonists and NAMs reported in the literature. The antagonist XAP044 $\left(\mathbf{1 0}, \mathrm{IC}_{50}=5.5 \mu \mathrm{M}\right)$ binds within the VFD and has shown efficacy in both in vivo and in vitro experiments such as anxiety-, depression-, and fear-related behavioral tasks and electrophysiology (Gee et al., 2014). Originally labeled a Group II mGlu receptor antagonist ( $\mathrm{mGlu}_{2}$ and $\mathrm{mGlu}_{3}$ ), LY341495 (11) was also found to have efficacy at $\mathrm{mGlu}_{4}, \mathrm{mGlu}_{7}$, and $\mathrm{mGlu}_{8}$ with $\mathrm{IC}_{50 \text { s }}$ of $22,0.99$, and $0.173 \mu \mathrm{M}$, respectively (Kingston et al., 1998) and has been used to study both groups of $\mathrm{mGlu}$ receptor since its discovery.

The mGlu 7 NAM 6-(4-methoxyphenyl)-5-methyl-3-pyridin4-ylisoxazolo[4,5-c]pyridin-4(5H)-one (MMPIP, 12), reported in 2007, has been used for several studies involving $\mathrm{mGlu}_{7}$ (Suzuki et al., 2007). MMPIP is able to inhibit the response of L-AP4, but its efficacy was later shown to be context-dependent. For example, the potency $\left(\mathrm{IC}_{50}\right)$ of MMPIP was $70 \mathrm{nM}$ in a calcium mobilization assay utilizing cells expressing $G_{\alpha 15}$ versus $718 \mathrm{nM}$ in a thallium flux assay with cells expressing $\mathrm{G}_{\alpha \mathrm{i} / \mathrm{o}}$, suggesting that its effects may be dependent on cellular background. Further, MMPIP was not effective in blocking an $\mathrm{mGlu}_{7}$-mediated depression of synaptic transmission in electrophysiological studies (Niswender et al., 2010). ADX71743, reported in 2013, exhibits an $\mathrm{IC}_{50}$ of 63 and $88 \mathrm{nM}$ at human and rat $\mathrm{mGlu}_{7}$, respectively (Kalinichev et al., 2013). However, it also exhibits low activity at mGlu 2 (Kalinichev et al., 2013; Reed et al., 2017) and possesses an electrophilic ketone moiety that could result in covalent modification and subsequent offtarget effects. Most recently, Reed et al. (2017) have successfully developed a series of novel, chemically-distinct mGlu 7 NAMs based upon a phenylbenzamide scaffold. One of the analogs, VU6010608 (13), exhibited modest potency $\left(\mathrm{IC}_{50}=759 \mathrm{nM}\right)$, but was cleared rapidly in rats $(64.2 \mathrm{~mL} / \mathrm{min} / \mathrm{kg})$ and exhibited low levels of brain penetration, making it challenging for in vivo CNS studies (Reed et al., 2017). These existing and emerging tools, coupled with mGlu $_{7}$ knockout mice, have provided an initial toolbox to begin elucidation of the function of $\mathrm{mGlu}_{7}$ in normal and pathological conditions.

\section{mGlu $_{7}$ IN SYNAPTIC TRANSMISSION AND PLASTICITY}

Inhibition of neurotransmitter release by $\mathrm{mGlu}_{7}$ is believed to be mediated by the inhibition of $\mathrm{N}$-type and $\mathrm{P} / \mathrm{Q}$-type calcium channels through interactions with $\mathrm{G}_{\beta \gamma}$, PKC, PICK1, and reductions in intracellular cAMP (Millán et al., 2002, 2003; Perroy et al., 2002; Martín et al., 2007). Millan and Colleagues demonstrated that activation of cerebrocortical $\mathrm{mGlu}_{7}$ with L-AP4 inhibited N-type calcium channels in a PKA- and PKCindependent manner, suggesting that the inhibition was caused via interactions with $\mathrm{G}_{\beta \gamma}$. These authors also demonstrated that mGlu $_{7}$-mediated decreases in cAMP could reduce spontaneous glutamate release in the cerebral cortex (Millán et al., 2002). Additionally, Perroy et al. (2000) demonstrated that P/Q-type calcium channels were inhibited via a PKC-dependent pathway, where $\mathrm{G}_{\mathrm{i} / \mathrm{o}}$ and/or $\mathrm{G}_{\beta \gamma}$ can stimulate the PLC pathway in cultured cerebellar granule cells. They also showed that the scaffolding protein, PICK1, facilitates the interaction between $\mathrm{mGlu}_{7}$ and $\mathrm{PKC}$, and is required for receptor-mediated $\mathrm{P} / \mathrm{Q}$-type calcium channel inhibition in this context (Perroy et al., 2002). In contrast, Martín et al. (2007) demonstrated that $\mathrm{mGlu}_{7}$ inhibited hippocampal P/Q-type calcium channels in a PKC-independent manner. The $\mathrm{mGlu}_{7}$-mediated inhibition of glutamate release is also dependent on interactions with calmodulin (CaM), where activated CaM allows for the displacement of $\mathrm{G}_{\beta \gamma}$ from $\mathrm{mGlu}_{7}$ and the subsequent downregulation of calcium influx into the cell via calcium channel inhibition (O'Connor et al., 1999). Moreover, mGluy's interaction with MacMARCKS (macrophage myristoylated alanine-rich C-kinase substrate) competitively antagonizes CaM-mediated calcium channel inhibition (Bertaso et al., 2006).

mGlu 7 's position within the active zone and its ability to modulate neurotransmitter release has led to numerous studies focused on its role in synaptic plasticity. Two major forms of synaptic plasticity include LTP and LTD, which are persistent changes in synaptic strength that are thought to be correlates of learning and memory (Bliss and Collingridge, 1993; Takeuchi et al., 2014). The role of $\mathrm{mGlu}_{7}$ in synaptic plasticity has been best characterized within the hippocampus at several distinct synapses. $\mathrm{mGlu}_{7}$ was first reported to mediate a form of LTD occurring in stratum radiatum interneurons within area CA3 (Laezza et al., 1999). At excitatory synapses onto interneurons expressing calcium-permeable AMPA receptors, LTP could be induced by high frequency stimulation and blocked by the Group II and Group III mGlu antagonist, LY341495. Further pharmacological experiments confirmed the specific involvement of $\mathrm{mGlu}_{7}$ : only a high concentration of L-AP4 depressed synaptic transmission at these synapses and a Group II mGlu agonist showed no effect. A similar form of plasticity was later described at mossy fiber inputs onto SLINs in area CA3 (Pelkey et al., 2005). At SLINs expressing calcium-permeable AMPA receptors, 
high frequency stimulation of mossy fibers induced an LTD that required $\mathrm{mGlu}_{7}$ activation and PKC-dependent depression of neurotransmitter release through $\mathrm{P} / \mathrm{Q}$-type voltage gated calcium channels (Pelkey et al., 2005, 2006). Interestingly, in slices pretreated with L-AP4, internalization of $\mathrm{mGlu}_{7}$ receptors revealed the ability of these synapses to undergo LTP instead of LTD in response to the same electrical stimulus. Surface expression of $\mathrm{mGlu}_{7}$, therefore, regulates the direction of plasticity at these synapses, making mGlu $_{7}$ a "metaplastic switch" that can modulate feedforward inhibition in area CA3.

An additional class of interneurons in which mGlu - $^{-}$ mediated plasticity has been implicated is the OLM interneuron population within the stratum oriens of areas CA3 and CA1. At excitatory inputs onto OLM interneurons, $\mathrm{mGlu}_{7}$ expression is preferentially enriched (Shigemoto et al., 1996) and proposed to be recruited by extracellular-leucine-rich repeat fibronectin type III domain containing 1, or ELFN1 (Tomioka et al., 2014). Sylwestrak and Ghosh demonstrated that ELFN1 knockdown in OLM interneurons decreases short-term facilitation and increases presynaptic release probability. Conversely, overexpression of ELFN1 in parvalbumin interneurons leads to short-term facilitation when these synapses typically undergo short-term depression (Sylwestrak and Ghosh, 2012). In slices from Elfn $1^{-/-}$mice, presynaptic release probability, short term facilitation, and LTP are reduced in patch-clamp recordings from OLM interneurons (Tomioka et al., 2014). Although this evidence is indirect, it suggests that $\mathrm{mGlu}_{7}$ may be involved in these forms of synaptic plasticity since $\mathrm{mGlu}_{7}$ is likely to be a major regulator of presynaptic release probability at these synapses due to its recruitment by ELFN1.

In addition to its role as an autoreceptor on excitatory terminals, $\mathrm{mGlu}_{7}$ is also located on the terminals of interneurons within the hippocampus and modulates the release of GABA (Somogyi et al., 2003; Summa et al., 2013). This function of $\mathrm{mGlu}_{7}$ is required for LTP in wild-type animals at SCCA1 synapses through a mechanism of disinhibition (Klar et al., 2015). Importantly, deficits in LTP at this particular synapse have been reported in several models of NDDs (Jiang et al., 1998; Moretti et al., 2006; von der Brelie et al., 2006). At SC-CA1 synapses, $\mathrm{mGlu}_{7}$ is the only presynaptic mGlu receptor present in adult animals and activation of $\mathrm{mGlu}_{7}$ has been repeatedly shown to reduce field potentials at SC-CA1 (Baskys and Malenka, 1991; Ayala et al., 2008; Jalan-Sakrikar et al., 2014). Klar et al. (2015) demonstrated that $\mathrm{mGlu}_{7}$ activation by the agonist LSP4-2022 also reduces evoked inhibitory post-synaptic currents recorded from CA1 pyramidal cells. LTP induced by high-frequency stimulation was blocked by ADX71743, but only when GABAergic transmission was intact. Recently, we showed that a chemically distinct $\mathrm{mGlu}_{7}$ NAM, VU6010608, also blocked LTP induced by high-frequency stimulation at SC-CA1 synapses (Reed et al., 2017). Interestingly, hippocampal slices from $\mathrm{Grm} 7^{-/-}$mice have been reported to exhibit similar levels of LTP when compared to WT controls, but decreased short-term potentiation following high-frequency stimulation (Bushell et al., 2002). In these studies, slices from $G r m 7^{-/-}$mice showed reduced facilitation during the high-frequency train, an effect that was also seen with ADX71743 by Klar et al. (2015). The presence of LTP in $G r m 7^{-/-}$slices may be due to compensatory mechanisms during development, such as retained expression of $\mathrm{mGlu}_{8}$, which is present at SC-CA1 synapses earlier in development (Ayala et al., 2008). Re-expression of $\mathrm{mGlu}_{8}$ is not unprecedented as the selective $\mathrm{mGlu}_{8}$ agonist (S)-3,4DCPG was recently shown to reduce synaptic transmission at SC-CA1 in slices from pilocarpine-treated rats, but not in those of age-matched controls (Dammann et al., 2018). While further studies will be needed to explain the current discrepancy between genetic and pharmacological approaches, these data indicate that $\mathrm{mGlu}_{7}$ regulates high-frequency transmission at SC-CA1 synapses. Recently, Martín et al. (2018) demonstrated that prolonged activation of $\mathrm{mGlu}_{7}$ leads to potentiation of excitatory post-synaptic currents recorded by pyramidal cells in CA1. This potentiation of neurotransmitter release is dependent on PLC and the vesicle release proteins Munc132 and Rim $1 \alpha$. These studies indicate that, under conditions of high-frequency stimulation, $\mathrm{mGlu}_{7}$ activation favors potentiation of excitatory transmission, which could be an additional mechanism by which $\mathrm{mGlu}_{7}$ modulates long-term plasticity in the hippocampus.

Beyond the hippocampus, a role for $\mathrm{mGlu}_{7}$ in LTP has also been established within the amygdala. Synaptic plasticity in the hippocampus is believed to underlie associative learning and working memory, whereas plasticity in the amygdala is associated with aversion and emotional learning (Brasted et al., 2003; Sigurdsson et al., 2007). The allosteric agonist AMN082 has been shown to block LTP at thalamo-amygdala synapses in slices from rats and mice (Fendt et al., 2008, 2013). This effect correlates with the ability of direct injection of AMN082 into the amygdala to block the acquisition of fear-potentiated startle behavior in rats (Fendt et al., 2008) and fear learning in mice (Fendt et al., 2008, 2013). Interestingly, Grm $7^{-/-}$mice exhibit a general deficit in fear learning and decreased LTP at thalamoamygdala synapses (Fendt et al., 2013). Reduction of LTP by both an agonist and gene ablation may be explained by AMN082's ability to cause rapid internalization of $\mathrm{mGlu}_{7}$ receptors (Pelkey et al., 2007). This would suggest that AMN082 can act as a functional antagonist by decreasing surface expression and, therefore, receptor signaling. This hypothesis is further supported by the ability of the mGlu $_{7}$ antagonist XAP044 to block LTP within the amygdala, inhibit acquisition of conditioned fear, and reduce anxiety-like behavior (Gee et al., 2014). Together, these studies demonstrate that $\mathrm{mGlu}_{7}$ promotes plasticity within the amygdala, which is in line with its involvement in behaviors of fear and anxiety.

\section{ROLE OF mGlu 7 IN NDD-ASSOCIATED PHENOTYPES}

Core symptoms and comorbidities of NDDs can include, but are not limited to: cognitive impairment, seizures, mood disorders, social deficits, and motor impairments (Mannion and Leader, 2013; Doshi-Velez et al., 2014). Many studies have demonstrated that modulation of $\mathrm{mGlu}_{7}$ function via genetic 
and/or pharmacologic techniques is able to mimic some of these phenotypes in animal models, and these studies will be reviewed here.

\section{COGNITION}

$\mathrm{mGlu}_{7}$ knockout animals $\left(\mathrm{Grm} 7^{-/-}\right)$show deficits in tasks that test cognitive functioning. In a conditioned taste aversion task, which measures amygdala-dependent aversive learning, mice were given saccharin along with an intraperitoneal injection of the control, saline, or $\mathrm{LiCl}$, which evokes malaise. In this task, $\mathrm{Grm} 7^{-/-}$mice did not associate the adverse effects of $\mathrm{LiCl}$ to saccharin in comparison to wild-type littermates, exhibiting a deficit in fear learning (Masugi et al., 1999). In addition, Masugi et al. (1999) and Goddyn et al. (2008, 2015) demonstrated that Grm $7^{-/-}$mice exhibit less freezing than wild-type animals in cued and contextual fear conditioning paradigms. Together, these results indicate a role for $\mathrm{mGlu}_{7}$ in aversion learning, and also suggest that the loss of $\mathrm{mGlu}_{7}$ causes impairments in these learning paradigms.

$\mathrm{mGlu}_{7}$ has also been demonstrated to play a role in cognitive tasks that do not rely on fearful or aversive stimuli. CallaertsVegh et al. (2006) showed that $G r m 7^{-/-}$mice exhibit impaired short-term working memory in 4- and 8-arm radial maze tasks, committing more errors (visits to previously baited arms or un-baited arms) than their wild-type counterparts. Conversely, Grm $7^{-/-}$mice performed similarly to wild-type animals in radial maze tasks when they were modified to assess long-term memory. Furthermore, both Callaerts-Vegh et al. (2006) and Goddyn et al. (2015) have reported that the loss of $\mathrm{mGlu}_{7}$ causes increased latency to locate a platform in the Morris water maze task of spatial memory. Interestingly, $\mathrm{Grm} 7^{-/-}$mice performed similarly to wild-type animals after increased training and in un-cued trials (Callaerts-Vegh et al., 2006). Together, these data demonstrate that $\mathrm{mGlu}_{7}$ may play specific roles in tasks involving working and spatial memory.

Pharmacological studies have further confirmed a role for $\mathrm{mGlu}_{7}$ in learning and memory. Hikichi et al. (2010) showed that administration of MMPIP, an mGlu 7 NAM, to wild-type mice reduced performance in object recognition and location tasks, suggesting that $\mathrm{mGlu}_{7}$ is also involved in recognition memory. MMPIP also attenuates conditioned taste aversion learning in rats (Klakotskaia et al., 2013). Interestingly, MMPIP improved cognitive performance in Y-maze and object recognition assays in a mouse model of neuropathic pain with no effect on shamtreated animals (Palazzo et al., 2015). As discussed above, MMPIP exhibits cellular background-dependent differences in vitro, and also had no effect in an electrophysiological study of at SC-CA1 synapses in the hippocampus (Niswender et al., 2010), which may complicate interpretation of in vivo data. Inhibition of $\mathrm{mGlu}_{7}$ with the antagonist XAP044 also resulted in reduced freezing in mice during a contextual fear conditioning task, further supporting a role for mGlu7 in amygdala function (Gee et al., 2014). Activation of $\mathrm{mGlu}_{7}$ with an allosteric agonist, AMN082, has been shown to modulate both the acquisition and extinction of conditioned fear, though the results seem to contradict findings from studies performed with XAP044 and $\mathrm{Grm} 7^{-/-}$animals (Fendt et al., 2008, 2013; Goddyn et al., 2008; Siegl et al., 2008; Dobi et al., 2013; Gee et al., 2014). Administration of AMN082 impairs the acquisition and enhances the extinction of fear learning (Fendt et al., 2008, 2013; Siegl et al., 2008; Dobi et al., 2013), but knockout animals exhibit similar phenotypes in conditioned fear paradigms (Goddyn et al., 2008; Fendt et al., 2013). AMN082 appears to exhibit a task-dependent phenotype, where $\mathrm{mGlu}_{7}$ activation facilitates between-session extinction, but not within-session extinction in a fear conditioning model (Toth et al., 2012; Fendt et al., 2013). AMN082 was also shown to have effects in social fear; it impaired extinction and recall when administered prior to the social fear extinction task, but not when given before social fear conditioning (Slattery et al., 2017). However, Ahnaou et al. (2016) demonstrated that AMN082 produced similar sleep-wake and hypothermia phenotypes in $G r m 7^{-/-}$and wild-type mice, suggesting that there may be off-target effects elicited by the compound. Additionally, administration of VU6005649, an $\mathrm{mGlu}_{7 / 8}$ PAM, to wild-type mice, increases freezing in contextual fear conditioning (Abe et al., 2017).

\section{SEIZURES}

Seizures are often present in patients with NDDs, and $\mathrm{mGlu}_{7}$ and its interacting proteins have been implicated in seizure activity. Sansig et al. (2001) observed that $G r m 7^{-/-}$mice suffered from spontaneous sensory stimulus-seizures and were also more susceptible to subconvulsant doses of PTZ and bicuculline than their heterozygous or wild-type littermates. In addition, reduction of mGlu $_{7}$ activity with the NAM ADX71743 was sufficient to induce absence seizures (Tassin et al., 2016). Disruption of proteins that interact with $\mathrm{mGlu}_{7}$ can also induce seizures in mice (Bertaso et al., 2008; Tomioka et al., 2014). For example, PICK1 is a PDZ-domain containing protein that interacts with the $\mathrm{C}$-terminus of $\mathrm{mGlu}_{7}$. The protein-protein interaction between PICK1 and $\mathrm{mGlu}_{7}$ is important for stable $\mathrm{mGlu}_{7}$ cell surface expression, proper trafficking of $\mathrm{mGlu}_{7}$ to presynaptic active zones, and also for inhibition of $\mathrm{P} / \mathrm{Q}$ type calcium channels. Disruption of the interaction between PICK1 and $\mathrm{mGlu}_{7}$ appears to interfere with $\mathrm{mGlu}_{7}$ 's inhibitory activity via decreased cell surface stability/expression or improper signaling and trafficking, resulting in a seizure phenotype in mice (Perroy et al., 2002; Bertaso et al., 2008; Zhang et al., 2008).

As mentioned previously, ELFN1 is a transmembrane protein that has been demonstrated to recruit $\mathrm{mGlu}_{7}$ to distinct cell populations in the hippocampus and cortex (Tomioka et al., 2014). Most recently, ELFN1 was also shown to be a trans-synaptic allosteric modulator of Group III mGlu receptors; receptor modulation occurs through an ELFN1mediated alteration of G-protein coupling efficiency to the Group III mGlu receptors (Dunn et al., 2018). Of note, ELFN1 mutations clustered in the region required for $\mathrm{mGlu}_{7}$ recruitment have been found in patients with epilepsy and ADHD (Dolan and Mitchell, 2013; Tomioka et al., 2014), and ELFN1 knockout $\left(E l f n 1^{-/-}\right)$animals exhibit a similar seizure phenotype to 
Grm7 $7^{-/-}$animals (Tomioka et al., 2014). Interestingly, Elfn $1^{-/-}$ mice also exhibit ADHD-like phenotypes such as hyperactivity and impulsivity. Dolan and Mitchell (2013) showed that Elfn $1^{-/-}$ animals display hyperlocomotion and increased activity in an open field. Administration of amphetamine to Elfn $1^{-/-}$mice was able to attenuate hyperlocomotion, similar to the effects of stimulant therapies for ADHD patients. Tomioka et al. (2014) also demonstrated that Elfn $1^{-/-}$mice displayed more spontaneous activity than wild-type animals and also exhibited decreased immobility in a forced swim test, which are behaviors suggestive of hyperactivity. Elfn $1^{-/-}$mice spent more time in the open arms during an EPM task compared to wildtype littermates. These data are typically indicative of anxiolytic effects; however, Elfn $1^{-/-}$mice showed no preferences between the light and dark boxes of the light-dark box transition task. Based on this finding, the authors hypothesized that the results of the EPM were indicative of impulsivity. Together, these data suggest a role for the ELFN1-mGlu 7 complex in seizures and in other disorders.

\section{MOOD DISORDERS}

$\mathrm{mGlu}_{7}$ modulation has also been demonstrated to impact behavioral models of mood disorders such as anxiety or depression, which are common comorbidities seen in NDDs (Matson and Cervantes, 2014). The amygdala and hippocampus, areas of high $\mathrm{mGlu}_{7}$ expression, are brain regions known for their importance in anti-anxiety and anti-depressive action (Shin and Liberzon, 2010). In comparison to cognitive tasks, where reductions in $\mathrm{mGlu}_{7}$ cause deficits, the loss of $\mathrm{mGlu}_{7}$ has been reported to result in anti-depressive and anxiolytic effects in these domains. For example, Cryan et al. (2003) showed that Grm7-/animals spend more time in the open arms than their wild-type counterparts in an EPM paradigm, demonstrating that the loss of the receptor causes anxiolytic activity. In a light-dark box task, the knockout animals have a reduced latency to enter a covered, dark compartment as well as an increased number of transitions into an open, brightly lit compartment than wildtype mice (Cryan et al., 2003). Callaerts-Vegh et al. (2006) demonstrated that $\mathrm{Grm} 7^{-/-}$mice bury fewer marbles than wildtype animals in a marble burying task, which also measures anxiety-like behavior in rodents. ADX71743, the $\mathrm{mGlu}_{7}$-selective NAM, causes similar results in EPM, and reduces marble burying in wild-type mice (Kalinichev et al., 2013). Administration of the NAM MMPIP also reduces marble burying, consistent with the Grm7 $7^{-/-}$phenotype (Palazzo et al., 2015). In tail suspension or forced swim tasks, where immobility is indicative of depressionlike behavior, $G r m 7^{-/-}$mice are less immobile than wild-type animals (Cryan et al., 2003). In wild-type mice, the antagonist XAP044 also increases time in open arms in EPM and decreases immobility in tail suspension, recapitulating data from studies using knockout animals (Gee et al., 2014). In a mouse model of neuropathic pain, the NAM MMPIP also reduces immobility time during tail suspension (Palazzo et al., 2015). The $\mathrm{mGlu}_{7}$ agonist AMN082 reduces immobility in tail suspension and forced swim tasks, and MMPIP can block the effect of AMN082 (O'Connor and Cryan, 2013; Pałucha-Poniewiera and Pilc, 2013).
In summary, $\mathrm{mGlu}_{7}$ has been implicated in a range of behaviors in rodent models, many of which mimic those reported in rodent models of NDDs.

\section{GENETIC ASSOCIATIONS BETWEEN $\mathrm{mGlu}_{7}$ AND NDDs}

Genetic associations between NDDs and GRM7, the gene that encodes $\mathrm{mGlu}_{7}$ in humans, provide a link between experiments in rodent models and the clinical population. ASD affects as much as $1 \%$ of the world's population (Lai et al., 2014), and family studies have suggested that the heritability of ASD is about $83 \%$ (Sandin et al., 2017), which indicates a strong genetic component. Heterozygous deletions in GRM7 have been identified in three ASD patients by Gai et al. (2012), and in one patient by Liu et al. (2015). The latter patient exhibited language and cognitive impairments as well as hyperactivity, stereotyped behaviors, and deficits in social interaction (Liu et al., 2015). An additional ASD patient with a de novo point mutation in GRM7, resulting in a change from arginine to glutamate at amino acid 622, was reported by Sanders et al. (2012). This mutation affects the third transmembrane portion of the receptor. Yang and Pan (2013) identified the SNPs rs6782011 and rs779867, which encode a $\mathrm{C}$ to $\mathrm{T}$ change in intron 6 and a $\mathrm{T}$ to $\mathrm{C}$ or $\mathrm{T}$ to $\mathrm{G}$ change in intron 5 in GRM7, respectively. These two polymorphisms exhibited significant associations with ASD from a group of 22 ASD patients (Yang and Pan, 2013). In an Iranian cohort of 518 ASD patients, however, only rs779867 was identified as a SNP that associates GRM7 with ASD (Noroozi et al., 2016). rs779867 is a $\mathrm{T}$ to $\mathrm{C}$ or $\mathrm{T}$ to $\mathrm{G}$ polymorphism in intron 5 hypothesized to have effects on a MRG protein binding motif. MRG motifbinding proteins are thought to bind chromatin and function in the regulation of gene transcription (Chen et al., 2010).

Attention deficit hyperactivity disorder is characterized by inattention, hyperactivity and impulsivity (American Psychiatric Association, 2013). Its estimated prevalence around the world is $7.2 \%$ in children and $3.4 \%$ in adults (Fayyad et al., 2007; Thomas et al., 2015). A genome wide copy-number variation study revealed that rs7623055, which encodes a $G$ to $C$ or $\mathrm{G}$ to $\mathrm{T}$ change, was significantly associated with $\mathrm{ADHD}$, and also identified six different deletions in GRM7 in patients with ADHD (Elia et al., 2011). Additionally, rs37952452 was found to have some association with ADHD in a study of 202 patients in Korea, though it was not significantly associated when using a case-control approach (Park et al., 2013). In contrast, neither rs37952452 nor rs7623055 were found to be significantly associated with ADHD in a later study (Akutagava-Martins et al., 2014). Interestingly, ADHD patients with the G/A genotype of rs37952452 showed an improved response to methylphenidate in comparison to those with the G/G genotype (Park et al., 2014).

Rare mutations in GRM7 have also been implicated in undiagnosed NDDs. Whole-exome sequencing in 31 consanguineous Arab families with developmental delay and/or intellectual disability revealed two families with mutations in GRM7. Two brothers in the same family were homozygous for a $461 \mathrm{~T} / \mathrm{C}$ variant, which results in the missense mutation $\mathrm{I} 154 \mathrm{~T}$ in the ligand binding domain of $\mathrm{mGlu}_{7}$. The same study also 
identified two siblings (brother and sister) who are compound heterozygous for the mutations $1972 \mathrm{C} / \mathrm{T}$ and $2024 \mathrm{C} / \mathrm{A}$, which lead to missense mutations, R658W and T675Y, respectively, in the third transmembrane domain. These four patients share symptoms that include developmental delay, ID, brain malformations and seizures (Charng et al., 2016). In a different set of consanguineous families, exome sequencing identified two female cousins with the homozygous mutation 1757G/A, which results in a premature truncation of $\mathrm{mGlu}_{7}$ prior to its first transmembrane domain (W568*). These patients exhibit seizures, profound ID, microcephaly and leukodystrophy (Reuter et al., 2017). A search of the DECIPHER database (Firth et al., 2009) identified 69 patients with a deletion or duplication that included GRM7, although most of these also affected other genes. Three of these patients had a deletion or duplication restricted to the GRM7 gene and their phenotypes are included in Table 2.

\section{mGlu 7 IN MECP2-RELATED DISORDERS}

Preclinical research in the NDD field has focused largely on mouse models of genetic syndromes due to their high construct validity. RTT is a monogenetic disorder in which $\mathrm{mGlu}_{7}$ has recently gained particular interest as a potential therapeutic target (Gogliotti et al., 2017). RTT is a debilitating NDD affecting 1 in 20,000 births and is characterized by a period of normal development followed by sudden developmental regression and loss of acquired skills at 6 to 18 months of age. Following regression, RTT patients are burdened by lifelong symptoms that include repetitive hand clasping, limited speech, intellectual disability, motor impairment, apneas, and epilepsy (Neul et al., 2010). The majority of RTT cases can be attributed to loss-of-function mutations in the $\mathrm{X}$-linked gene $M E C P 2$, which encodes the transcriptional regulator methylCpG binding protein 2 (MeCP2) (Amir et al., 1999). Since this discovery, nearly two decades of research have yielded significant insight into the functions of MeCP2 within the brain. Of note, MECP2 mutations have also been identified in patients with ASD and ID independent of a RTT diagnosis (Couvert et al., 2001; Carney et al., 2003), suggesting that pathways involving MeCP2 may underlie NDDs more broadly. MeCP2 is canonically thought to repress gene transcription through binding to methylated $\mathrm{CpG}$ dinucleotides and recruiting repressor complexes; however, $\mathrm{MeCP} 2$ has also been shown to activate gene transcription and play roles in long-range regulation of chromatin structure, mRNA splicing and microRNA processing (Guy et al., 2011). Although MeCP2 is involved in prenatal and postnatal development (Tate et al., 1996;

TABLE 2 | Summary of GRM7 mutations identified in NDD patients.

\begin{tabular}{|c|c|c|c|c|c|c|}
\hline Type & Chromosome 3 position & $\begin{array}{l}\text { Nucleotide/ } \\
\text { protein } \\
\text { change } \\
\text { NM_00844.3 }\end{array}$ & $\begin{array}{l}\text { Location in } \\
\text { transcript } \\
\text { NM_00844.3 }\end{array}$ & Zygosity & Phenotype & Source \\
\hline Duplication & $6209671-6981117$ & & 5' UTR and Exon 1 & Heterozygous & $\begin{array}{l}\text { Behavioral } \\
\text { abnormality, ID }\end{array}$ & DECIPHER 289768 \\
\hline Point mutation & 6861849 & $\begin{array}{l}\text { c. } T 461 T>C \\
\text { p.I154T }\end{array}$ & Exon 1 & Homozygous & $\begin{array}{l}\text { Developmental } \\
\text { delay, seizures, } \\
\text { hypotonia, atrophy, } \\
\text { thin corpus } \\
\text { callosum }\end{array}$ & Charng et al., 2016 \\
\hline Deletion & $7053179-7144453$ & & $\begin{array}{l}\text { Intron } 1 / 2 \text { and Exon } \\
2\end{array}$ & Heterozygous & ASD & Gai et al., 2012 \\
\hline Deletion & $70664629-7172715$ & & Exon 2 & Heterozygous & ASD & Gai et al., 2012 \\
\hline Deletion & $7065422-7172715$ & & Exon 2 & Heterozygous & ASD & Gai et al., 2012 \\
\hline Deletion & $7257514-7442882$ & & Exons 3-5 & Heterozygous & $\begin{array}{l}\text { Global } \\
\text { developmental } \\
\text { delay }\end{array}$ & DECIPHER 356330 \\
\hline Deletion & $7221090-7524552$ & & Exons 3-7 & Heterozygous & ASD & Liu et al., 2015 \\
\hline Point mutation & 7578663 & $\begin{array}{l}\text { c. } 1757 \mathrm{G}>\mathrm{A} \\
\text { p.W586* }\end{array}$ & Exon 8 & Homozygous & $\begin{array}{l}\text { Developmental } \\
\text { delay, ID, } \\
\text { microcephaly, } \\
\text { seizures, } \\
\text { leukodystrophy }\end{array}$ & Reuter et al., 2017 \\
\hline Point mutation & 7578771 & $\begin{array}{l}\text { c. } 1865 \mathrm{G}>\mathrm{A} \\
\text { p. } R 622 \mathrm{Q}\end{array}$ & Exon 8 & Heterozygous & ASD & $\begin{array}{l}\text { Sanders et al., } \\
2012\end{array}$ \\
\hline Point mutation & 7578878,7578930 & $\begin{array}{l}\text { c. } 1972 \mathrm{C}>\mathrm{T} \\
\text { p. } \mathrm{R} 658 \mathrm{~W}, \\
\text { c. } 2024 \mathrm{C}>\mathrm{A} \\
\text { p. } T 675 \mathrm{~K}\end{array}$ & Exon 8 & $\begin{array}{l}\text { Compound } \\
\text { Heterozygous }\end{array}$ & $\begin{array}{l}\text { Developmental } \\
\text { delay, ID, } \\
\text { hypotonia, } \\
\text { hypomyelination, } \\
\text { brain atrophy, } \\
\text { seizures }\end{array}$ & Charng et al., 2016 \\
\hline Duplication & 7509664-7878406 & & Exons 8-10 & Heterozygous & ID, microcephaly & DECIPHER 288108 \\
\hline
\end{tabular}


Shahbazian et al., 2002; Bedogni et al., 2016), phenotypes of Mecp2 knockout mice can be reversed if Mecp2 expression is reintroduced in adult animals (Guy et al., 2007). Similarly, ablation of Mecp2 expression in adult mice following normal development is sufficient to recapitulate the phenotype of constitutive Mecp2 knockout mice (McGraw et al., 2011). MeCP2 is thus critical for proper neuronal function throughout life and there exists a therapeutic window to improve disease severity, even at adult stages. These proof-of-concept studies have fueled programs to develop MECP2 replacement strategies, along with parallel efforts to identify targets downstream of MeCP2 dysfunction that may be amenable to pharmacological manipulation.

$\mathrm{mGlu}_{7}$ is one of three mGlu receptors found to be decreased at the mRNA level in a RTT mouse model (Bedogni et al., 2016). These mGlu receptors represent a potential point of access to normalize synaptic function in RTT. Consistent with this initial report, we have shown that $\mathrm{mGlu}_{7}$ protein expression is significantly decreased in motor cortex autopsy samples from RTT patients compared to those of controls matched for age, sex, and postmortem interval (Gogliotti et al., 2017). In global Mecp2 knockout mice, $\mathrm{mGlu}_{7}$ protein expression is decreased in a brainregion specific manner with a notable reduction in hippocampal synaptosomal fractions. This correlates with reduced depression of synaptic transmission at SC-CA1 synapses by LSP4-2022 in slices from RTT model mice, which can be restored by a PAM. Additionally, pre-application of two structurally distinct Group III mGlu receptor PAMs, VU0422288 and VU0155094, to slices was able to restore deficient LTP at SC-CA1 synapses in RTT model mice. Ablation of Mecp2 selectively from GABAergic neurons is sufficient for LTP impairment (Chao et al., 2010); therefore, rescue of LTP by mGlu $_{7}$ potentiation is consistent with the proposed model by which $\mathrm{mGlu}_{7}$-mediated inhibition of GABA release is required for LTP at SC-CA1 synapses (Klar et al., 2015).

At the behavioral level, $\mathrm{mGlu}_{7}$ potentiation by intraperitoneal administration of the brain penetrant PAM, VU0422288, is able to improve performance in assays of cognition in RTT model mice (Gogliotti et al., 2017). While many studies in $G r m 7^{-/-}$ mice have implicated a role for $\mathrm{mGlu}_{7}$ in learning and memory (Hölscher et al., 2005; Callaerts-Vegh et al., 2006; Goddyn et al., 2008), this is the first report of $\mathrm{mGlu}_{7}$ activity being modulated in a positive direction to reverse a deficit in cognition. VU0422288 is also able to increase performance in a social novelty task and reduce the number of apneas detected by whole body plethysmography (Gogliotti et al., 2017). These data suggest that $\mathrm{mGlu}_{7}$ potentiation may be a valid approach to address multiple RTT-associated symptom domains. It is important to note that these experiments used mice with a global deletion of Mecp2. As RTT is most commonly caused by MECP2 point mutations in humans, it will be important to elucidate the effect of various point mutations on $\mathrm{mGlu}_{7}$ expression/function to identify patient subpopulations that would be predicted to benefit from an $\mathrm{mGlu}_{7}$ PAM.

$\mathrm{mGlu}_{7}$ has also been investigated for its therapeutic utility in a mouse of MDS. In contrast to RTT, MDS occurs when the region of the $\mathrm{X}$ chromosome containing MECP2 is duplicated or triplicated, and is predicted to account for $1 \%$ of cases of unexplained X-linked intellectual disability (Lugtenberg et al., 2009). MDS patients present with infantile hypotonia, autismassociated symptoms, speech impairment, respiratory infections, and epilepsy (Ramocki et al., 2010). This disorder highlights the point that precise regulation of $\mathrm{MeCP} 2$ expression is required for normal brain function and that excess MeCP2 protein is detrimental. Fisher et al. (2017) tested whether $\mathrm{mGlu}_{7}$ protein levels are affected in MeCP2-Tg1 mice, a model for MDS. Contrary to a hypothesis of bidirectional regulation, $\mathrm{mGlu}_{7}$ protein levels are unchanged in most brain regions in $\mathrm{MeCP} 2-$ Tg1 mice. Furthermore, neither genetic reduction of $\mathrm{mGlu}_{7}$ protein levels or administration of the mGlu 7 NAM ADX71743 had any impact on anxiety and fear learning phenotypes in MeCP2-Tg1 mice (Fisher et al., 2017). These findings suggest that that $\mathrm{mGlu}_{7}$ expression/function may only be affected by MeCP2 hypofunction and not overexpression. More studies are warranted to understand the molecular interaction between MeCP2 and $\mathrm{mGlu}_{7}$ expression. This information will inform future drug development of $\mathrm{mGlu}_{7}$ PAMs for RTT and other NDDs in which MECP2 mutations have been identified.

\section{CONCLUSION}

Neurodevelopmental disorders are a prevalent group of disorders with limited treatment options and $\mathrm{mGlu}_{7}$ represents one potential access point for pharmacological intervention. GRM7 gene disruptions identified in patients with NDDs provide clinical rationale for this approach. Pre-clinical studies in rodent models suggest that decreased $\mathrm{mGlu}_{7}$ function is sufficient to mimic phenotypes that correlate to NDD symptom domains and that positive modulation of $\mathrm{mGlu}_{7}$ activity can improve some deficits, specifically in a mouse model of RTT. However, NDDs are highly heterogeneous and are likely the result of unique molecular pathologies that converge to produce similar circuit and behavioral phenotypes. Therefore, further studies are needed to identify and understand which subpopulations may benefit from an $\mathrm{mGlu}_{7}$-mediated therapy. In parallel, further development of improved tool compounds will facilitate studies focused on understanding $\mathrm{mGlu}_{7}$ receptor function in brain circuits and behaviors associated with NDDs.

\section{AUTHOR CONTRIBUTIONS}

NF and MS equally contributed to the first draft of this review. All authors read and edited the manuscript prior to submission.

\section{FUNDING}

NF was supported by NIH training grants T32 GM007628 and F31 MH113259. MS was supported by T32 GM007628. $\mathrm{CL}$ received funding from William $\mathrm{K}$. Warren, Jr. and the William K. Warren Foundation and is supported by the William K. Warren, Jr. Chair in Medicine. CN received funding from the National Institutes of Mental Health (R21MH102548 and 
R01MH113543; the latter jointly with CL), the Department of Defense Congressionally Directed Medical Research Program (W81XWH-17-1-0266), and rettsyndrome.org. This review makes use of data generated by the DECIPHER community.

\section{REFERENCES}

Abe, M., Seto, M., Gogliotti, R. G., Loch, M. T., Bollinger, K. A., Chang, S., et al. (2017). Discovery of VU6005649, a CNS penetrant mGlu7/8 receptor PAM derived from a series of Pyrazolo[1,5-a]pyrimidines. ACS Med. Chem. Lett. 8, 1110-1115. doi: 10.1021/acsmedchemlett.7b00317

Acher, F., Pin, J.-P., Goudet, C., Eschalier, A., Busserolles, J., Rigault, D., et al. (2012). Hypophosphorous Acid Derivatives Having Antihyperalgic Activity and Biological Applications Thereof. US Patent 9212196B2. Paris: Universite Paris Descartes.

Ahnaou, A., Raeyemaekers, L., Huysmans, H., and Drinkenburg, W. H. I. M. (2016). Off-target potential of AMN082 on sleep EEG and related physiological variables: evidence from mGluR7 (-/-) mice. Behav. Brain Res. 311, 287-297. doi: 10.1016/j.bbr.2016.05.035

Akutagava-Martins, G. C., Salatino-Oliveira, A., Bruxel, E. M., Genro, J. P., Mota, N. R., Polanczyk, G. V., et al. (2014). Lack of association between the GRM7 gene and attention deficit hyperactivity disorder. Psychiatr. Genet. 24, 281-282. doi: 10.1097/YPG.0000000000000059

Amir, R. E., Van den Veyver, I. B., Wan, M., Tran, C. Q., Francke, U., and Zoghbi, H. Y. (1999). Rett syndrome is caused by mutations in X-linked MECP2, encoding methyl-CpG-binding protein 2. Nat. Genet. 23, 185-188. doi: 10.1038/ 13810

American Psychiatric Association (2013). Diagnostic and Statistical Manual of Mental Disorder, 5th Edn. Arlington, VA: American Psychiatric Publishing.

Ayala, J. E., Niswender, C. M., Luo, Q., Banko, J. L., and Conn, P. J. (2008). Group III mGluR regulation of synaptic transmission at the SC-CA1 synapse is developmentally regulated. Neuropharmacology 54, 804-814. doi: 10.1016/j. neuropharm.2007.12.009

Baskys, A., and Malenka, R. C. (1991). Agonists at metabotropic glutamate receptors presynaptically inhibit EPSCs in neonatal rat hippocampus. J. Physiol. 444, 687-701. doi: 10.1113/jphysiol.1991.sp018901

Bedogni, F., Cobolli Gigli, C., Pozzi, D., Rossi, R. L., Scaramuzza, L., Rossetti, G., et al. (2016). Defects during mecp 2 null embryonic cortex development precede the onset of overt neurological symptoms. Cereb. Cortex 26, 2517-2529. doi: 10.1093/cercor/bhv078

Bertaso, F., Lill, Y., Airas, J. M., Espeut, J., Blahos, J., Bockaert, J., et al. (2006). MacMARCKS interacts with the metabotropic glutamate receptor type 7 and modulates $G$ protein-mediated constitutive inhibition of calcium channels. J. Neurochem. 99, 288-298. doi: 10.1111/j.1471-4159.2006.04121.x

Bertaso, F., Zhang, C., Scheschonka, A., de Bock, F., Fontanaud, P., Marin, P., et al. (2008). PICK1 uncoupling from mGluR7a causes absence-like seizures. Nat. Neurosci. 11, 940-948. doi: 10.1038/nn.2142

Binet, V., Duthey, B., Lecaillon, J., Vol, C., Quoyer, J., Labesse, G., et al. (2007). Common structural requirements for heptahelical domain function in class A and class C G protein-coupled receptors. J. Biol. Chem. 282, 12154-12163. doi: 10.1074/jbc.M611071200

Bliss, T. V., and Collingridge, G. L. (1993). A synaptic model of memory: long-term potentiation in the hippocampus. Nature 361, 31-39. doi: 10.1038/361031a0

Boyle, C. A., Boulet, S., Schieve, L. A., Cohen, R. A., Blumberg, S. J., YearginAllsopp, M., et al. (2011). Trends in the prevalence of developmental disabilities in US children, 1997-2008. Pediatrics 127, 1034-1042. doi: 10.1542/peds.20102989

Brasted, P. J., Bussey, T. J., Murray, E. A., and Wise, S. P. (2003). Role of the hippocampal system in associative learning beyond the spatial domain. Brain 126(Pt 5), 1202-1223. doi: 10.1093/brain/awg103

Bushell, T. J., Sansig, G., Collett, V. J., van der Putten, H., and Collingridge, G. L. (2002). Altered short-term synaptic plasticity in mice lacking the metabotropic glutamate receptor mGlu7. Thescientificworldjournal 2, 730-737. doi: 10.1100/ tsw.2002.146

Callaerts-Vegh, Z., Beckers, T., Ball, S. M., Baeyens, F., Callaerts, P. F., Cryan, J. F., et al. (2006). Concomitant deficits in working memory and fear
A full list of centers who contributed to the generation of the data is available from http://decipher.sanger.ac.uk and via email from decipher@sanger.ac.uk. Funding for the project was provided by the Wellcome Trust.

extinction are functionally dissociated from reduced anxiety in metabotropic glutamate receptor 7-deficient mice. J. Neurosci. 26, 6573-6582. doi: 10.1523/ JNEUROSCI.1497-06.2006

Carney, R. M., Wolpert, C. M., Ravan, S. A., Shahbazian, M., Ashley-Koch, A., Cuccaro, M. L., et al. (2003). Identification of MeCP2 mutations in a series of females with autistic disorder. Pediatr. Neurol. 28, 205-211. doi: 10.1016/S08878994(02)00624-0

Cartmell, J., and Schoepp, D. D. (2000). Regulation of neurotransmitter release by metabotropic glutamate receptors. J. Neurochem. 75, 889-907. doi: 10.1046/j. 1471-4159.2000.0750889.x

Chao, H.-T., Chen, H., Samaco, R. C., Xue, M., Chahrour, M., Yoo, J., et al. (2010). Dysfunction in GABA signalling mediates autism-like stereotypies and Rett syndrome phenotypes. Nature 468, 263-269. doi: 10.1038/nature09582

Charng, W.-L., Karaca, E., Coban Akdemir, Z., Gambin, T., Atik, M. M., $\mathrm{Gu}$, S., et al. (2016). Exome sequencing in mostly consanguineous Arab families with neurologic disease provides a high potential molecular diagnosis rate. BMC Med. Genomics 9:42. doi: 10.1186/s12920-0160208-3

Chen, M., Tominaga, K., and Pereira-Smith, O. M. (2010). Emerging role of the MORF/MRG gene family in various biological processes, including aging. Ann. N. Y. Acad. Sci. 1197, 134-141. doi: 10.1111/j.1749-6632.2010. 05197.x

Christensen, D. L., Baio, J., Van Naarden Braun, K., Bilder, D., Charles, J., Constantino, J. N., et al. (2016). Prevalence and characteristics of autism spectrum disorder among children aged 8 years-autism and developmental disabilities monitoring network, 11 sites, United States, 2012. MMWR Surveill. Summ. 65, 1-23. doi: 10.15585/mmwr.ss6503al

Corti, C., Restituito, S., Rimland, J. M., Brabet, I., Corsi, M., Pin, J. P., et al. (1998). Cloning and characterization of alternative mRNA forms for the rat metabotropic glutamate receptors mGluR7 and mGluR8. Eur. J. Neurosci. 10, 3629-3641. doi: 10.1046/j.1460-9568.1998.00371.x

Couvert, P., Bienvenu, T., Aquaviva, C., Poirier, K., Moraine, C., Gendrot, C., et al. (2001). MECP2 is highly mutated in X-linked mental retardation. Hum. Mol. Genet. 10, 941-946. doi: 10.1093/hmg/10.9.941

Cryan, J. F., Kelly, P. H., Neijt, H. C., Sansig, G., Flor, P. J., and van Der Putten, H. (2003). Antidepressant and anxiolytic-like effects in mice lacking the group III metabotropic glutamate receptor mGluR7. Eur. J. Neurosci. 17, 2409-2417. doi: 10.1046/j.1460-9568.2003.02667.x

Dalezios, Y., Luján, R., Shigemoto, R., Roberts, J. D. B., and Somogyi, P. (2002). Enrichment of mGluR7a in the presynaptic active zones of GABAergic and nonGABAergic terminals on interneurons in the rat somatosensory cortex. Cereb. Cortex 12, 961-974. doi: 10.1093/cercor/12.9.961

Dammann, F., Kirschstein, T., Guli, X., Müller, S., Porath, K., Rohde, M., et al. (2018). Bidirectional shift of group III metabotropic glutamate receptormediated synaptic depression in the epileptic hippocampus. Epilepsy Res. 139, 157-163. doi: 10.1016/j.eplepsyres.2017.12.002

Dev, K. K., Nakanishi, S., and Henley, J. M. (2001). Regulation of mglu7 receptors by proteins that interact with the intracellular C-terminus. Trends Pharmacol. Sci. 22, 355-361. doi: 10.1016/S0165-6147(00)01684-9

Dobi, A., Sartori, S. B., Busti, D., Van der Putten, H., Singewald, N., Shigemoto, R., et al. (2013). Neural substrates for the distinct effects of presynaptic group III metabotropic glutamate receptors on extinction of contextual fear conditioning in mice. Neuropharmacology 66, 274-289. doi: 10.1016/j.neuropharm.2012.05. 025

Dolan, J., and Mitchell, K. J. (2013). Mutation of Elfn1 in mice causes seizures and hyperactivity. PLoS One 8:e80491. doi: 10.1371/journal.pone.0080491

Doshi-Velez, F., Ge, Y., and Kohane, I. (2014). Comorbidity clusters in autism spectrum disorders: an electronic health record time-series analysis. Pediatrics 133, e54-e63. doi: 10.1542/peds.2013-0819

Doumazane, E., Scholler, P., Zwier, J. M., Trinquet, E., Rondard, P., and Pin, J.P. (2011). A new approach to analyze cell surface protein complexes reveals 
specific heterodimeric metabotropic glutamate receptors. FASEB J. 25, 66-77. doi: 10.1096/fj.10-163147

Dunn, H. A., Patil, D. N., Cao, Y., Orlandi, C., and Martemyanov, K. A. (2018). Synaptic adhesion protein ELFN1 is a selective allosteric modulator of group III metabotropic glutamate receptors in trans. Proc. Natl. Acad. Sci. U.S.A. 115, 5022-5027. doi: 10.1073/pnas.1722498115

El Moustaine, D., Granier, S., Doumazane, E., Scholler, P., Rahmeh, R., Bron, P., et al. (2012). Distinct roles of metabotropic glutamate receptor dimerization in agonist activation and G-protein coupling. Proc. Natl. Acad. Sci. U.S.A. 109, 16342-16347. doi: 10.1073/pnas.1205838109

Elia, J., Glessner, J. T., Wang, K., Takahashi, N., Shtir, C. J., Hadley, D., et al. (2011). Genome-wide copy number variation study associates metabotropic glutamate receptor gene networks with attention deficit hyperactivity disorder. Nat. Genet. 44, 78-84. doi: 10.1038/ng.1013

Fayyad, J., De Graaf, R., Kessler, R., Alonso, J., Angermeyer, M., Demyttenaere, K., et al. (2007). Cross-national prevalence and correlates of adult attention-deficit hyperactivity disorder. Br. J. Psychiatry 190, 402-409. doi: 10.1192/bjp.bp.106. 034389

Fendt, M., Imobersteg, S., Peterlik, D., Chaperon, F., Mattes, C., Wittmann, C., et al. (2013). Differential roles of $\mathrm{mGlu}(7)$ and $\mathrm{mGlu}(8)$ in amygdala-dependent behavior and physiology. Neuropharmacology 72, 215-223. doi: 10.1016/j. neuropharm.2013.04.052

Fendt, M., Schmid, S., Thakker, D. R., Jacobson, L. H., Yamamoto, R., Mitsukawa, K., et al. (2008). mGluR7 facilitates extinction of aversive memories and controls amygdala plasticity. Mol. Psychiatry 13, 970-979. doi: 10.1038/sj. mp.4002073

Firth, H. V., Richards, S. M., Bevan, A. P., Clayton, S., Corpas, M., Rajan, D., et al. (2009). DECIPHER: database of chromosomal imbalance and phenotype in humans using ensembl resources. Am. J. Hum. Genet. 84, 524-533. doi: 10.1016/j.jhg.2009.03.010

Fisher, N. M., Gogliotti, R. G., Vermudez, S. A. D., Stansley, B. J., Conn, P. J., and Niswender, C. M. (2017). Genetic reduction or negative modulation of mGlu7 does not impact anxiety and fear learning phenotypes in a mouse model of MECP2 duplication syndrome. ACS Chem. Neurosci. 9, 2210-2217. doi: 10.1021/acschemneuro.7b00414

Flor, P. J., Van Der Putten, H., Rüegg, D., Lukic, S., Leonhardt, T., Bence, M., et al. (1997). A novel splice variant of a metabotropic glutamate receptor, human mGluR7b. Neuropharmacology 36, 153-159. doi: 10.1016/S0028-3908(96) 00176-1

Gai, X., Xie, H. M., Perin, J. C., Takahashi, N., Murphy, K., Wenocur, A. S., et al. (2012). Rare structural variation of synapse and neurotransmission genes in autism. Mol. Psychiatry 17, 402-411. doi: 10.1038/mp.2011.10

Gee, C. E., Peterlik, D., Neuhäuser, C., Bouhelal, R., Kaupmann, K., Laue, G., et al. (2014). Blocking metabotropic glutamate receptor subtype 7 (mGlu7) via the Venus flytrap domain (VFTD) inhibits amygdala plasticity, stress, and anxiety-related behavior. J. Biol. Chem. 289, 10975-10987. doi: 10.1074/jbc. M113.542654

Goddyn, H., Callaerts-Vegh, Z., and D'Hooge, R. (2015). Functional dissociation of group III metabotropic glutamate receptors revealed by direct comparison between the behavioral profiles of knockout mouse lines. Int. J. Neuropsychopharmacol. 18:yv053. doi: 10.1093/ijnp/ pyv053

Goddyn, H., Callaerts-Vegh, Z., Stroobants, S., Dirikx, T., Vansteenwegen, D., Hermans, D., et al. (2008). Deficits in acquisition and extinction of conditioned responses in mGluR7 knockout mice. Neurobiol. Learn. Mem. 90, 103-111. doi: 10.1016/j.nlm.2008.01.001

Gogliotti, R. G., Senter, R. K., Fisher, N. M., Adams, J., Zamorano, R., Walker, A. G., et al. (2017). mGlu7 potentiation rescues cognitive, social, and respiratory phenotypes in a mouse model of Rett syndrome. Sci. Transl. Med. 9:eaai7459. doi: 10.1126/scitranslmed.aai7459

Goudet, C., Vilar, B., Courtiol, T., Deltheil, T., Bessiron, T., Brabet, I., et al. (2012). A novel selective metabotropic glutamate receptor 4 agonist reveals new possibilities for developing subtype selective ligands with therapeutic potential. FASEB J. 26, 1682-1693. doi: 10.1096/fj.11195941

Guy, J., Cheval, H., Selfridge, J., and Bird, A. (2011). The role of MeCP2 in the brain. Annu. Rev. Cell Dev. Biol. 27, 631-652. doi: 10.1146/annurev-cellbio-092910154121
Guy, J., Gan, J., Selfridge, J., Cobb, S., and Bird, A. (2007). Reversal of neurological defects in a mouse model of Rett syndrome. Science 315, 1143-1147. doi: 10. $1126 /$ science. 1138389

Hajasova, Z., Canestrelli, C., Acher, F., Noble, F., and Marie, N. (2018). Role of mGlu7 receptor in morphine rewarding effects is uncovered by a novel orthosteric agonist. Neuropharmacology 131, 424-430. doi: 10.1016/j. neuropharm.2018.01.002

Hikichi, H., Murai, T., Okuda, S., Maehara, S., Satow, A., Ise, S., et al. (2010). Effects of a novel metabotropic glutamate receptor 7 negative allosteric modulator, 6-(4-methoxyphenyl)-5-methyl-3-pyridin-4-ylisoxazonolo[4,5c]pyridin-4(5H)-one (MMPIP), on the central nervous system in rodents. Eur. J. Pharmacol. 639, 106-114. doi: 10.1016/j.ejphar.2009.08.047

Hölscher, C., Schmid, S., Pilz, P. K. D., Sansig, G., van der Putten, H., and Plappert, C. F. (2005). Lack of the metabotropic glutamate receptor subtype 7 selectively modulates Theta rhythm and working memory. Learn. Mem. 12, 450-455. doi: 10.1101/lm.98305

Hu, W. F., Chahrour, M. H., and Walsh, C. A. (2014). The diverse genetic landscape of neurodevelopmental disorders. Annu. Rev. Genomics Hum. Genet. 15, 195-213. doi: 10.1146/annurev-genom-090413-025600

Jalan-Sakrikar, N., Field, J. R., Klar, R., Mattmann, M. E., Gregory, K. J., Zamorano, R., et al. (2014). Identification of positive allosteric modulators VU0155094 (ML397) and VU0422288 (ML396) reveals new insights into the biology of metabotropic glutamate receptor 7. ACS Chem. Neurosci. 5, 12211237. doi: $10.1021 / \mathrm{cn} 500153 \mathrm{z}$

Jiang, Y. H., Armstrong, D., Albrecht, U., Atkins, C. M., Noebels, J. L., Eichele, G., et al. (1998). Mutation of the Angelman ubiquitin ligase in mice causes increased cytoplasmic p53 and deficits of contextual learning and long-term potentiation. Neuron 21, 799-811. doi: 10.1016/S0896-6273(00) 80596-6

Jingami, H., Nakanishi, S., and Morikawa, K. (2003). Structure of the metabotropic glutamate receptor. Curr. Opin. Neurobiol. 13, 271-278. doi: 10.1016/S09594388(03)00067-9

Kalinichev, M., Le Poul, E., Boléa, C., Girard, F., Campo, B., Fonsi, M., et al. (2014). Characterization of the novel positive allosteric modulator of the metabotropic glutamate receptor 4 ADX88178 in rodent models of neuropsychiatric disorders. J. Pharmacol. Exp. Ther. 350, 495-505. doi: 10.1124/ jpet.114.214437

Kalinichev, M., Rouillier, M., Girard, F., Royer-Urios, I., Bournique, B., Finn, T., et al. (2013). ADX71743, a potent and selective negative allosteric modulator of metabotropic glutamate receptor 7: in vitro and in vivo characterization. J. Pharmacol. Exp. Ther. 344, 624-636. doi: 10.1124/jpet.112.200915

Kammermeier, P. J. (2015). Constitutive activity of metabotropic glutamate receptor 7. BMC Neurosci. 16:17. doi: 10.1186/s12868-015-0154-6

Kingston, A. E., Ornstein, P. L., Wright, R. A., Johnson, B. G., Mayne, N. G., Burnett, J. P., et al. (1998). LY341495 is a nanomolar potent and selective antagonist of group II metabotropic glutamate receptors. Neuropharmacology 37, 1-12. doi: 10.1016/S0028-3908(97)00191-3

Kinoshita, A., Shigemoto, R., Ohishi, H., van der Putten, H., and Mizuno, N. (1998). Immunohistochemical localization of metabotropic glutamate receptors, mGluR7a and mGluR7b, in the central nervous system of the adult rat and mouse: a light and electron microscopic study. J. Comp. Neurol. 393, 332-352. doi: 10.1002/(SICI)1096-9861(19980413)393:3<332::AID-CNE6>3.0.CO;2-2

Klakotskaia, D., Ramsey, A. K., Fowler, S. W., Serfozo, P., Simonyi, A., and Schachtman, T. R. (2013). Effects of group II and III metabotropic glutamate receptor ligands on conditioned taste aversion learning. Behav. Brain Res. 253, 9-16. doi: 10.1016/j.bbr.2013.06.032

Klar, R., Walker, A. G., Ghose, D., Grueter, B. A., Engers, D. W., Hopkins, C. R., et al. (2015). Activation of metabotropic glutamate receptor 7 is required for induction of long-term potentiation at SC-CA1 synapses in the hippocampus. J. Neurosci. 35, 7600-7615. doi: 10.1523/JNEUROSCI.4543-14. 2015

Kniazeff, J., Bessis, A.-S., Maurel, D., Ansanay, H., Prézeau, L., and Pin, J.-P. (2004). Closed state of both binding domains of homodimeric mGlu receptors is required for full activity. Nat. Struct. Mol. Biol. 11, 706-713. doi: 10.1038/ nsmb794

Kosinski, C. M., Risso Bradley, S., Conn, P. J., Levey, A. I., Landwehrmeyer, G. B., Penney, J. B., et al. (1999). Localization of metabotropic glutamate receptor 7 mRNA and mGluR7a protein in the rat basal ganglia. J. Comp. Neurol. 415, 
266-284. doi: 10.1002/(SICI)1096-9861(19991213)415:2<266::AID-CNE9>3.0. $\mathrm{CO} ; 2-7$

Kunishima, N., Shimada, Y., Tsuji, Y., Sato, T., Yamamoto, M., Kumasaka, T., et al. (2000). Structural basis of glutamate recognition by a dimeric metabotropic glutamate receptor. Nature 407, 971-977. doi: 10.1038/35039564

Laezza, F., Doherty, J. J., and Dingledine, R. (1999). Long-term depression in hippocampal interneurons: joint requirement for pre- and postsynaptic events. Science 285, 1411-1414. doi: 10.1126/science.285.5432.1411

Lai, M.-C., Lombardo, M. V., and Baron-Cohen, S. (2014). Autism. Lancet 383, 896-910. doi: 10.1016/S0140-6736(13)61539-1

Le Poul, E., Boléa, C., Girard, F., Poli, S., Charvin, D., Campo, B., et al. (2012). A potent and selective metabotropic glutamate receptor 4 positive allosteric modulator improves movement in rodent models of Parkinson's disease. J. Pharmacol. Exp. Ther. 343, 167-177. doi: 10.1124/jpet.112.196063

Lebourgeois, S., Vilpoux, C., Jeanblanc, J., Acher, F., Marie, N., Noble, F., et al. (2018). Pharmacological activation of mGlu4 and mGlu7 receptors, by LSP29166, reduces ethanol consumption and relapse in rat. Neuropharmacology 133, 163-170. doi: 10.1016/j.neuropharm.2018.01.031

Levitz, J., Habrian, C., Bharill, S., Fu, Z., Vafabakhsh, R., and Isacoff, E. Y. (2016). Mechanism of assembly and cooperativity of homomeric and heteromeric metabotropic glutamate receptors. Neuron 92, 143-159. doi: 10.1016/j.neuron. 2016.08.036

Liu, Y., Zhang, Y., Zhao, D., Dong, R., Yang, X., Tammimies, K., et al. (2015). Rare de novo deletion of metabotropic glutamate receptor 7 (GRM7) gene in a patient with autism spectrum disorder. Am. J. Med. Genet. Part B Neuropsychiatr. Genet. 168B, 258-264. doi: 10.1002/ajmg.b.32306

Lugtenberg, D., Kleefstra, T., Oudakker, A. R., Nillesen, W. M., Yntema, H. G., Tzschach, A., et al. (2009). Structural variation in Xq28: MECP2 duplications in $1 \%$ of patients with unexplained XLMR and in $2 \%$ of male patients with severe encephalopathy. Eur. J. Hum. Genet. 17, 444-453. doi: 10.1038/ejhg.2008.208

Mannion, A., and Leader, G. (2013). Comorbidity in autism spectrum disorder: a literature review. Res. Autism Spectr. Disord. 7, 1595-1616. doi: 10.1016/j.rasd. 2013.09.006

Martín, R., Ferrero, J. J., Collado-Alsina, A., Aguado, C., Luján, R., Torres, M., et al. (2018). Bidirectional modulation of glutamatergic synaptic transmission by metabotropic glutamate type 7 receptors at Schaffer collateral-CA1 hippocampal synapses. J. Physiol. 596, 921-940. doi: 10.1113/JP275371

Martín, R., Torres, M., and Sánchez-Prieto, J. (2007). mGluR7 inhibits glutamate release through a PKC-independent decrease in the activity of $\mathrm{P} / \mathrm{Q}$-type $\mathrm{Ca}^{+}$ channels and by diminishing cAMP in hippocampal nerve terminals. Eur. J. Neurosci. 26, 312-322. doi: 10.1111/j.1460-9568.2007.05660.x

Masugi, M., Yokoi, M., Shigemoto, R., Muguruma, K., Watanabe, Y., Sansig, G., et al. (1999). Metabotropic glutamate receptor subtype 7 ablation causes deficit in fear response and conditioned taste aversion. J. Neurosci. 19, 955-963. doi: 10.1523/JNEUROSCI.19-03-00955.1999

Matson, J. L., and Cervantes, P. E. (2014). Commonly studied comorbid psychopathologies among persons with autism spectrum disorder. Res. Dev. Disabil. 35, 952-962. doi: 10.1016/j.ridd.2014.02.012

McGraw, C. M., Samaco, R. C., and Zoghbi, H. Y. (2011). Adult neural function requires MeCP2. Science 333:186. doi: 10.1126/science.1206593

Millán, C., Castro, E., Torres, M., Shigemoto, R., and Sánchez-Prieto, J. (2003). Coexpression of metabotropic glutamate receptor 7 and $\mathrm{N}$-type $\mathrm{Ca}\left(2^{+}\right)$channels in single cerebrocortical nerve terminals of adult rats. J. Biol. Chem. 278, 23955-23962. doi: 10.1074/jbc.M211471200

Millán, C., Luján, R., Shigemoto, R., and Sánchez-Prieto, J. (2002). The inhibition of glutamate release by metabotropic glutamate receptor 7 affects both $\left[\mathrm{Ca}^{+}\right] \mathrm{c}$ and cAMP: evidence for a strong reduction of $\mathrm{Ca}_{2}^{+}$entry in single nerve terminals. J. Biol. Chem. 277, 14092-14101. doi: 10.1074/jbc.M109044200

Mitsukawa, K., Yamamoto, R., Ofner, S., Nozulak, J., Pescott, O., Lukic, S., et al. (2005). A selective metabotropic glutamate receptor 7 agonist: activation of receptor signaling via an allosteric site modulates stress parameters in vivo. Proc. Natl. Acad. Sci. U.S.A. 102, 18712-18717. doi: 10.1073/pnas.05080 63102

Moretti, P., Levenson, J. M., Battaglia, F., Atkinson, R., Teague, R., Antalffy, B., et al. (2006). Learning and memory and synaptic plasticity are impaired in a mouse model of Rett syndrome. J. Neurosci. 26, 319-327. doi: 10.1523/JNEUROSCI. 2623-05.2006
Muto, T., Tsuchiya, D., Morikawa, K., and Jingami, H. (2007). Structures of the extracellular regions of the group II/III metabotropic glutamate receptors. Proc. Natl. Acad. Sci. U.S.A. 104, 3759-3764. doi: 10.1073/pnas.0611577104

Neul, J. L., Kaufmann, W. E., Glaze, D. G., Christodoulou, J., Clarke, A. J., Bahi-Buisson, N., et al. (2010). Rett syndrome: revised diagnostic criteria and nomenclature. Ann. Neurol. 68, 944-950. doi: 10.1002/ana.22124

Niswender, C. M., and Conn, P. J. (2010). Metabotropic glutamate receptors: physiology, pharmacology, and disease. Annu. Rev. Pharmacol. Toxicol. 50, 295-322. doi: 10.1146/annurev.pharmtox.011008.145533

Niswender, C. M., Johnson, K. A., Miller, N. R., Ayala, J. E., Luo, Q., Williams, R., et al. (2010). Context-dependent pharmacology exhibited by negative allosteric modulators of metabotropic glutamate receptor 7. Mol. Pharmacol. 77, 459468. doi: $10.1124 / \mathrm{mol} .109 .058768$

Noroozi, R., Taheri, M., Movafagh, A., Mirfakhraie, R., Solgi, G., Sayad, A., et al. (2016). Glutamate receptor, metabotropic 7 (GRM7) gene variations and susceptibility to autism: a case-control study. Autism Res. 9, 1161-1168. doi: 10.1002/aur.1640

O'Connor, R. M., and Cryan, J. F. (2013). The effects of mGlu7 receptor modulation in behavioural models sensitive to antidepressant action in two mouse strains. Behav. Pharmacol. 24, 105-113. doi: 10.1097/FBP.0b013e32835efc78

O'Connor, V., El Far, O., Bofill-Cardona, E., Nanoff, C., Freissmuth, M., Karschin, A., et al. (1999). Calmodulin dependence of presynaptic metabotropic glutamate receptor signaling. Science 286, 1180-1184. doi: 10.1126/science.286. 5442.1180

Palazzo, E., Romano, R., Luongo, L., Boccella, S., De Gregorio, D., Giordano, M. E., et al. (2015). MMPIP, an mGluR7-selective negative allosteric modulator, alleviates pain and normalizes affective and cognitive behavior in neuropathic mice. Pain 156, 1060-1073. doi: 10.1097/j.pain.0000000000000150

Pałucha-Poniewiera, A., and Pilc, A. (2013). A selective mGlu7 receptor antagonist MMPIP reversed antidepressant-like effects of AMN082 in rats. Behav. Brain Res. 238, 109-112. doi: 10.1016/j.bbr.2012.10.004

Park, S., Jung, S.-W., Kim, B.-N., Cho, S.-C., Shin, M.-S., Kim, J.-W., et al. (2013). Association between the GRM7 rs3792452 polymorphism and attention deficit hyperacitiveity disorder in a Korean sample. Behav. Brain Funct. 9:1. doi: 10. 1186/1744-9081-9-1

Park, S., Kim, B.-N., Cho, S.-C., Kim, J.-W., Kim, J. I., Shin, M.-S., et al. (2014). The metabotropic glutamate receptor subtype $7 \mathrm{rs} 3792452$ polymorphism is associated with the response to methylphenidate in children with attentiondeficit/hyperactivity disorder. J. Child Adolesc. Psychopharmacol. 24, 223-227. doi: 10.1089/cap.2013.0079

Pelkey, K. A., Lavezzari, G., Racca, C., Roche, K. W., and McBain, C. J. (2005). mGluR7 is a metaplastic switch controlling bidirectional plasticity of feedforward inhibition. Neuron 46, 89-102. doi: 10.1016/j.neuron.2005.02.011

Pelkey, K. A., Topolnik, L., Lacaille, J.-C., and McBain, C. J. (2006). Compartmentalized $\mathrm{Ca}\left(2^{+}\right)$channel regulation at divergent mossy-fiber release sites underlies target cell-dependent plasticity. Neuron 52, 497-510. doi: 10. 1016/j.neuron.2006.08.032

Pelkey, K. A., Yuan, X., Lavezzari, G., Roche, K. W., and McBain, C. J. (2007). mGluR7 undergoes rapid internalization in response to activation by the allosteric agonist AMN082. Neuropharmacology 52, 108-117. doi: 10.1016/j. neuropharm.2006.07.020

Perroy, J., El Far, O., Bertaso, F., Pin, J. P., Betz, H., Bockaert, J., et al. (2002). PICK1 is required for the control of synaptic transmission by the metabotropic glutamate receptor 7. EMBO J. 21, 2990-2999. doi: 10.1093/emboj/cdf313

Perroy, J., Prezeau, L., De Waard, M., Shigemoto, R., Bockaert, J., and Fagni, L. (2000). Selective blockade of P/Q-type calcium channels by the metabotropic glutamate receptor type 7 involves a phospholipase $\mathrm{C}$ pathway in neurons. J. Neurosci. 20, 7896-7904. doi: 10.1523/JNEUROSCI.20-21-07896.2000

Pin, J.-P., Galvez, T., and Prézeau, L. (2003). Evolution, structure, and activation mechanism of family 3/C G-protein-coupled receptors. Pharmacol. Ther. 98, 325-354. doi: 10.1016/S0163-7258(03)00038-X

Pin, J. P., Kniazeff, J., Liu, J., Binet, V., Goudet, C., Rondard, P., et al. (2005). Allosteric functioning of dimeric class C G-protein-coupled receptors. FEBS J. 272, 2947-2955. doi: 10.1111/j.1742-4658.2005.04728.x

Ramocki, M. B., Tavyev, Y. J., and Peters, S. U. (2010). The MECP2 duplication syndrome. Am. J. Med. Genet. Part A 152A, 1079-1088. doi: 10.1002/ajmg.a. 33184 
Reed, C. W., McGowan, K. M., Spearing, P. K., Stansley, B. J., Roenfanz, H. F., Engers, D. W., et al. (2017). VU6010608, a novel mGlu7 NAM from a series of N-(2-(1H-1,2,4-Triazol-1-yl)-5-(trifluoromethoxy)phenyl)benzamides. ACS Med. Chem. Lett. 8, 1326-1330. doi: 10.1021/acsmedchemlett.7b00429

Reuter, M. S., Tawamie, H., Buchert, R., Hosny Gebril, O., Froukh, T., Thiel, C., et al. (2017). Diagnostic yield and novel candidate genes by exome sequencing in 152 consanguineous families with neurodevelopmental disorders. JAMA Psychiatry 74, 293-299. doi: 10.1001/jamapsychiatry.2016.3798

Rondard, P., Liu, J., Huang, S., Malhaire, F., Vol, C., Pinault, A., et al. (2006). Coupling of agonist binding to effector domain activation in metabotropic glutamate-like receptors. J. Biol. Chem. 281, 24653-24661. doi: 10.1074/jbc. M602277200

Sanders, S. J., Murtha, M. T., Gupta, A. R., Murdoch, J. D., Raubeson, M. J., Willsey, A. J., et al. (2012). De novo mutations revealed by whole-exome sequencing are strongly associated with autism. Nature 485, 237-241. doi: 10.1038/nature10945

Sandin, S., Lichtenstein, P., Kuja-Halkola, R., Hultman, C., Larsson, H., and Reichenberg, A. (2017). The heritability of autism spectrum disorder. JAMA 318, 1182-1184. doi: 10.1001/jama.2017.12141

Sansig, G., Bushell, T. J., Clarke, V. R., Rozov, A., Burnashev, N., Portet, C., et al. (2001). Increased seizure susceptibility in mice lacking metabotropic glutamate receptor 7. J. Neurosci. 21, 8734-8745. doi: 10.1523/JNEUROSCI.21-22-08734. 2001

Schulz, H. L., Stohr, H., and Weber, B. H. F. (2002). Characterization of three novel isoforms of the metabotrobic glutamate receptor 7 (GRM7). Neurosci. Lett. 326, 37-40. doi: 10.1016/S0304-3940(02)00306-3

Selvam, C., Lemasson, I. A., Brabet, I., Oueslati, N., Karaman, B., Cabaye, A., et al. (2018). Increased potency and selectivity for group III metabotropic glutamate receptor agonists binding at dual sites. J. Med. Chem. 61, 1969-1989. doi: 10.1021/acs.jmedchem.7b01438

Shahbazian, M. D., Antalffy, B., Armstrong, D. L., and Zoghbi, H. Y. (2002). Insight into Rett syndrome: MeCP2 levels display tissue- and cell-specific differences and correlate with neuronal maturation. Hum. Mol. Genet. 11, 115-124. doi: 10.1093/hmg/11.2.115

Shigemoto, R., Kulik, A., Roberts, J. D., Ohishi, H., Nusser, Z., Kaneko, T., et al. (1996). Target-cell-specific concentration of a metabotropic glutamate receptor in the presynaptic active zone. Nature $381,523-525$. doi: $10.1038 / 381523 \mathrm{a} 0$

Shin, L. M., and Liberzon, I. (2010). The neurocircuitry of fear, stress, and anxiety disorders. Neuropsychopharmacology 35, 169-191. doi: 10.1038/npp.2009.83

Siegl, S., Flor, P. J., and Fendt, M. (2008). Amygdaloid metabotropic glutamate receptor subtype 7 is involved in the acquisition of conditioned fear. Neuroreport 19, 1147-1150. doi: 10.1097/WNR.0b013e328307f295

Sigurdsson, T., Doyère, V., Cain, C. K., and LeDoux, J. E. (2007). Long-term potentiation in the amygdala: a cellular mechanism of fear learning and memory. Neuropharmacology 52, 215-227. doi: 10.1016/j.neuropharm.2006.06. 022

Slattery, D. A., Neumann, I. D., Flor, P. J., and Zoicas, I. (2017). Pharmacological modulation of metabotropic glutamate receptor subtype 5 and 7 impairs extinction of social fear in a time-point-dependent manner. Behav. Brain Res. 328, 57-61. doi: 10.1016/j.bbr.2017.04.010

Somogyi, P., Dalezios, Y., Luján, R., Roberts, J. D. B., Watanabe, M., and Shigemoto, R. (2003). High level of mGluR7 in the presynaptic active zones of select populations of GABAergic terminals innervating interneurons in the rat hippocampus. Eur. J. Neurosci. 17, 2503-2520. doi: 10.1046/j.1460-9568.2003. 02697.x

Spooren, W., Lindemann, L., Ghosh, A., and Santarelli, L. (2012). Synapse dysfunction in autism: a molecular medicine approach to drug discovery in neurodevelopmental disorders. Trends Pharmacol. Sci. 33, 669-684. doi: 10. 1016/j.tips.2012.09.004

Sukoff Rizzo, S. J., Leonard, S. K., Gilbert, A., Dollings, P., Smith, D. L., Zhang, M.Y., et al. (2011). The metabotropic glutamate receptor 7 allosteric modulator AMN082: a monoaminergic agent in disguise? J. Pharmacol. Exp. Ther. 338, 345-352. doi: 10.1124/jpet.110.177378

Summa, M., Di Prisco, S., Grilli, M., Usai, C., Marchi, M., and Pittaluga, A. (2013). Presynaptic mGlu7 receptors control GABA release in mouse hippocampus. Neuropharmacology 66, 215-224. doi: 10.1016/j.neuropharm.2012. 04.020
Suzuki, G., Tsukamoto, N., Fushiki, H., Kawagishi, A., Nakamura, M., Kurihara, H., et al. (2007). In Vitro pharmacological characterization of novel isoxazolopyridone derivatives as allosteric metabotropic glutamate receptor 7 antagonists. J. Pharmacol. Exp. Ther. 323, 147-156. doi: 10.1124/jpet.107. 124701

Sylwestrak, E. L., and Ghosh, A. (2012). Elfn1 regulates target-specific release probability at CA1-interneuron synapses. Science 338, 536-540. doi: 10.1126/ science. 1222482

Sztainberg, Y., and Zoghbi, H. Y. (2016). Lessons learned from studying syndromic autism spectrum disorders. Nat. Neurosci. 19, 1408-1417. doi: 10.1038/nn.4420

Takeuchi, T., Duszkiewicz, A. J., and Morris, R. G. M. (2014). The synaptic plasticity and memory hypothesis: encoding, storage and persistence. Philos. Trans. R. Soc. Lond. B Biol. Sci. 369:20130288. doi: 10.1098/rstb.2013.0288

Tassin, V., Girard, B., Chotte, A., Fontanaud, P., Rigault, D., Kalinichev, M., et al. (2016). Phasic and tonic mGlu7 receptor activity modulates the thalamocortical network. Front. Neural Circ. 10:31. doi: 10.3389/fncir.2016.00031

Tate, P., Skarnes, W., and Bird, A. (1996). The methyl-CpG binding protein MeCP2 is essential for embryonic development in the mouse. Nat. Genet. 12, 205-208. doi: 10.1038/ng0296-205

Tateyama, M., Abe, H., Nakata, H., Saito, O., and Kubo, Y. (2004). Ligand-induced rearrangement of the dimeric metabotropic glutamate receptor 1alpha. Nat. Struct. Mol. Biol. 11, 637-642. doi: 10.1038/nsmb770

Thomas, R., Sanders, S., Doust, J., Beller, E., and Glasziou, P. (2015). Prevalence of attention-deficit/hyperactivity disorder: a systematic review and meta-analysis. Pediatrics 135, e994-e1001. doi: 10.1542/peds.2014-3482

Tomioka, N. H., Yasuda, H., Miyamoto, H., Hatayama, M., Morimura, N., Matsumoto, Y., et al. (2014). Elfn1 recruits presynaptic mGluR7 in trans and its loss results in seizures. Nat. Commun. 5:4501. doi: 10.1038/ncomms 5501

Toth, I., Dietz, M., Peterlik, D., Huber, S. E., Fendt, M., Neumann, I. D., et al. (2012). Pharmacological interference with metabotropic glutamate receptor subtype 7 but not subtype 5 differentially affects within- and between-session extinction of Pavlovian conditioned fear. Neuropharmacology 62, 1619-1626. doi: 10.1016/j.neuropharm.2011.10.021

van Loo, K. M., and Martens, G. J. (2007). Genetic and environmental factors in complex neurodevelopmental disorders. Curr. Genomics 8, 429-444. doi: $10.2174 / 138920207783591717$

von der Brelie, C., Waltereit, R., Zhang, L., Beck, H., and Kirschstein, T. (2006). Impaired synaptic plasticity in a rat model of tuberous sclerosis. Eur. J. Neurosci. 23, 686-692. doi: 10.1111/j.1460-9568.2006.04594.x

Yang, Y., and Pan, C. (2013). Role of metabotropic glutamate receptor 7 in autism spectrum disorders: a pilot study. Life Sci. 92, 149-153. doi: 10.1016/j.lfs.2012. 11.010

Zerbino, D. R., Achuthan, P., Akanni, W., Amode, M. R., Barrell, D., Bhai, J., et al. (2018). Ensembl 2018. Nucleic Acids Res. 46, D754-D761. doi: 10.1093/nar/ gkx1098

Zhang, C.-S., Bertaso, F., Eulenburg, V., Lerner-Natoli, M., Herin, G. A., Bauer, L., et al. (2008). Knock-in mice lacking the PDZ-ligand motif of mGluR7a show impaired PKC-dependent autoinhibition of glutamate release, spatial working memory deficits, and increased susceptibility to pentylenetetrazol. J. Neurosci. 28, 8604-8614. doi: 10.1523/JNEUROSCI.062808.2008

Conflict of Interest Statement: The authors declare that the research was conducted in the absence of any commercial or financial relationships that could be construed as a potential conflict of interest.

The reviewer FG and handling Editor declared their shared affiliation.

Copyright (๑) 2018 Fisher, Seto, Lindsley and Niswender. This is an open-access article distributed under the terms of the Creative Commons Attribution License (CC BY). The use, distribution or reproduction in other forums is permitted, provided the original author(s) and the copyright owner(s) are credited and that the original publication in this journal is cited, in accordance with accepted academic practice. No use, distribution or reproduction is permitted which does not comply with these terms. 